\title{
THE NATO ACTION AGAINST THE FEDERAL REPUBLIC OF YUGOSLAVIA: HUMANITARIAN INTERVENTION IN THE POST-COLD WAR ERA
}

\author{
Steven Wheatley, Faculty of Law, University of the West of England, \\ Bristol $^{*}$
}

\section{INTRODUCTION}

On 23 March 1999, the NATO Secretary-General, Javier Solana, delegated responsibility for the initiation of air strikes against the Federal Republic of Yugoslavia, ${ }^{1}$ to the NATO Supreme Commander, General Wesley Clark, following the failure of the Federal Republic to comply with NATO demands that it accept an interim political settlement on the future of Kosovo and end the excessive and disproportionate use of force employed by the Serb Army and Special Police Forces in the region. ${ }^{2}$ The stated aim of the military intervention, "Operation Allied Force", which commenced on 24 March 1999, was "to prevent more humanitarian suffering and more repression and violence against the civilian population of Kosovo .... a and bring an end to the humanitarian catastrophe . . . unfolding". 3

This article examines the legality of the NATO intervention. In doing so, it considers the background to the humanitarian tragedy which unfolded in Kosovo, the application of provisions on collective security under the Charter of the United Nations and, most importantly, the extent to which the international community recognises a right of intervention by military

\footnotetext{
My thanks to Dr Istvan Pogany (Warwick University), Dino Kritsiotis (Nottingham University) and Maria Lee (University Central Lancashire) for their helpful comments on an earlier version. All errors, of course, remain my own.

1 Federal Republic of Yugoslavia (FRY): (claimed) successor State to Yugoslavia, although not recognised as such by the international community - accordingly not permitted to participate in the United Nations, the Organization for Security and Co-Operation in Europe, or other international organisations (alternate name Serbia and Montenegro). Kosovo is a region of the Republic of Serbia, one of the constituent republics of the Federal Republic of Yugoslavia, with Montenegro. These constitutional niceties should not obscure the reality that the Federal Republic of Yugoslavia and Serbia are effectively controlled by President Milosevic, President of the Federal Republic of Yugoslavia: see, generally, "U.S. Department of State Serbia-Montenegro Country Report on Human Rights Practices for 1998", released by the Bureau of Democracy, Human Rights, and Labor, February 26 1999:

<http://www.state.gov/www/global/human rights/1998 hrp report/serbiamo.html>.

2 Whilst the intervention was carried out by North Atlantic Treaty Organisation (NATO) forces, and certain states, notably the United States of America, played a greater role than others, the fact that NATO forces remained under the political control of the organisation, which acts by consensus, means that those member states are 'jointly and severally' responsible for the actions of NATO forces under international law.
}

3 NATO Press Release (1999) 040, 23 March 1999. 
force to prevent humanitarian suffering. ${ }^{4}$ Such altruistic interventions have traditionally gone under the nom de guerre of humanitarian intervention. ${ }^{5}$ Whilst the doctrine is never explicitly invoked in the present instance, the humanitarian motives adduced by NATO States require us determine the legality of acts of humanitarian intervention more generally before considering its particular application here.

\section{THE BACKGROUND TO A TRAGEDY}

The roots of the 1998/9 humanitarian crisis in Kosovo may be traced directly to the large-scale offensives launched by the Serb authorities against the ethnic Albanian population in February 1998. ${ }^{6}$ These

4 'Intervention' is not limited, under international law, to military intervention; the term 'humanitarian intervention' is, however, "invariably" taken to mean intervention by "armed force": Verwey, "Humanitarian Intervention under International Law" (1985) XXXII Netherlands International Law Review 357 at $358-366$

The concern of this article is intervention by states and international organisations, not the actions of Non-Governmental Organisations in, for example, providing humanitarian aid to persons within a state without the consent of the government. See, on the latter issue, Weiss and Minear, "Do International Ethics Matter" (1991) 5 Ethics and International Affairs 197 at 212.

5 There is a wealth of literature on "humanitarian intervention": see, for example, Brownlie, "Humanitarian Intervention", in Moore (ed.) Law and Civil War in the Modern World (1974) 217; Lillich, "Humanitarian Intervention: A Reply to Ian Brownlie and a Plea for a Constructive Alternative", in Moore (ed.), id., 233; Brownlie, "Thoughts on Kind-Hearted Gunmen", in Lillich (ed.), Humanitarian Intervention and the United Nations (1973) 139; Fairley, "State Actors, Humanitarian Intervention and International Law: Reopening Pandora's Box" (1980) 10 Georgia. J. Int'l \& Comp. L. 29; Fonteyne, "The Customary International Law Doctrine of Humanitarian Intervention: Its Current Validity Under the U.N. Charter" (1974) 4 California Western International Law Journal 203; Franck and Rodley, "After Bangladesh: The Law of Humanitarian Intervention by Military Force" (1973) 67 AJIL 275; Greenwood, "Is there a right to humanitarian intervention?", (February 1993) The World Today 34; Malunczuk, Humanitarian Intervention and the Legitimacy of the Use of Force (1993); Murphy, Humanitarian Intervention: The United Nations in an Evolving World Order (1996); Nanda, "Tragedies in Northern Iraq, Liberia, Yugoslavia and Haiti - Revisiting the Validity of Humanitarian Intervention: Part I" (1992) 20 Denver Jnl of International Law and Politics 305; Sornarajah, "Internal Colonialism and Humanitarian Intervention" (1981) 11 Georgia. J. Int'l \& Comp. L. 138; Tesón, Humanitarian Intervention: An inquiry into law and morality (1997, 2nd. ed.); Verwey, supra n. 4.

6 The position of Kosovo within Serbia has for many years created political tensions, not only between the respective ethnic Serb and Albanian communities, but also between the Federal Republic of Yugoslavia and neighbouring States, particularly Albania. The primary cause of these tensions is the existence of a majority ethnic Albanian population within Kosovo, who, partly as a result of Serb mistreatment, demand independence from Serbia, integration into Albania or, as a minimum, the restoration of the special autonomous status granted to Kosovo under the 1974 (Socialist) Constitution of Yugoslavia removed under the regime of President Milosevic (who based his rise to power in Serbia/FRY on pursuing a policy of its removal): see, Mertus, "The Dayton Peace Accords: Lessons From the Past and for the Future", in 
offensives resulted in hundreds of Kosovar Albanians being killed, thousands fleeing their homes and an armed reaction from ethic-Albanian irregular forces. ${ }^{7}$ The military campaign "made no distinction between armed guerrillas and unarmed citizens. Whole villages were shelled, crops were burnt in the field and farm animals were incinerated in their barns. A quarter of a million people - a tenth of the entire population - [became] refugees" as a direct result of Serb actions. ${ }^{8}$

Whilst diplomatic attempts to resolve the crisis continued throughout 1998, predominately through the six-nation 'Contact Group', ${ }^{9}$ the North Atlantic Treaty Organisation (NATO) made a determination that military force would be used if the Federal Republic of Yugoslavia did not comply with the demands of the international community to end the violence in Kosovo, bring about a lasting political settlement for the region and prevent the humanitarian crisis unfolding. ${ }^{10}$ On 13 October 1998, activation orders (ACTORDs) were issued by NATO to allow it to carry out air strikes, if the Federal Republic of Yugoslavia continued to fail to comply with the demands of Security Council Resolution 1199.11 Following the issuing of the activation orders, diplomatic efforts to resolve the Kosovo crisis intensified and air strikes were not, at that point, carried out; the ACTORDs remained in place, however, with their clear, albeit implicit, threat that military force would be used if President Milosevic, of the Federal Republic of Yugoslavia, refused to compromise on the issue of Kosovo.

The diplomatic efforts undertaken resulted in an agreement between Milosevic and the United States envoy, Richard Holbrooke, ${ }^{12}$ under which the Federal Republic would allow NATO reconnaissance planes to overfly the region, ${ }^{13}$ and the Organisation for Security and Co-Operation in Europe (OSCE) to deploy a 2,000 strong 'Kosovo Verification Mission' to monitor a cease-fire, agreed between the Yugoslav authorities and the Kosovo Liberation Army. ${ }^{14}$ The final details of a political settlement, and of the deployment of an international monitoring force, were to be worked out at meetings between the Serb authorities and representatives of the Kosovar Albanian population at Rambouillet, France. The situation on the ground in Kosovo, however, continued to deteriorate, and when, after initially indicating its acceptance of the 'Rambouillet accord', 15 the

Cumper and Wheatley (eds.), Minority Rights in the 'New' Europe (1999) 261, at 263 - 4; also Woodward, Balkan Tragedy: Chaos and Dissolution After the Cold War (1995), passim.

7 Caplan, "International Diplomacy and the Crisis in Kosovo" (1998) 74 International Affairs 745 at 745.

8 Foreign Secretary Cook, Statement to the House of Commons, HC Debs. 19 October 1998, col. 953.

9 France, Germany, Italy, Russia, the United Kingdom and the United States.

10 Meeting of the North Atlantic Council in Foreign Ministers Session, "Statement on Kosovo": Press Communiqué M-NAC-2(98) 143, 8 December 1998.

11 Statement to the Press by the Secretary-General of NATO: <http://www.nato.int/docu/speech/1998/s981013a.htm>.

12 S/1998/953, annex: 14 October 1998.

13 Agreement NATO-Yugoslavia: Kosovo Verification Mission S/1998/991 (2310-98).

14 Agreement OSCE-Yugoslavia: Kosovo Verification Mission S/1998/978 (2010-98).

15 "Interim Agreement for Peace and Self-Government in Kosovo", agreed at Rambouillet on 23 February 1999. 
Federal Republic of Yugoslavia refused to sign the agreement, NATO commenced a military air campaign, which, in turn, precipitated an intensification of ethnic-cleansing by Serb forces in the region, and the creation of hundred of thousands of Kosovar Albanian refugees who fled to Albania and Macedonia.

After seventy-nine days of intensive NATO bombing, during which time three thousand separate bombing missions were flown, causing massive damage to the infrastructure of the Federal Republic, and numerous civilian deaths, agreement on a diplomatic initiative to end the crisis, and the NATO air campaign, was reached between western leaders and the Russian Federation at the 'G8' meeting on 6 May 1999. ${ }^{16}$ Faced with a united international community, the indictment of Milosevic by the International Criminal Tribunal for the former Yugoslavia on charges of war crimes, ${ }^{17}$ and the finalisation of plans for a massive ground invasion of Kosovo by a 170,000-strong force, the Federal Republic of Yugoslavia agreed to proposals presented to it by President Ahtisaari of Finland, representing the European Union, and Viktor Chernomyrdin, Special Representative of the President of the Russian Federation. ${ }^{18}$ That agreement was endorsed by the Security Council in Resolution 1244, ${ }^{19}$ with the Council demanding that the Federal Republic of Yugoslavia comply fully with the provisions in the Resolution..$^{20}$

Resolution 1244, adopted under Chapter VII of the Charter of the United Nations, reflected the two primary objectives of the international community: first, the ending of the humanitarian crisis in Kosovo and provision for the "safe and free return of all refugees and displaced persons to their homes"; 21 and, secondly, "the development of ... democratic and autonomous self-government" for the Kosovo region. ${ }^{22}$ In respect of the first objective, the Resolution demanded that the Federal Republic of Yugoslavia "put an immediate and verifiable end to violence

A summary of the draft interim agreement (prepared by the FCO) is available in Youngs, Oakes, and Bowers, "Kosovo: NATO and Military Action", HC Paper 99/34 (1999), Appendix I.

$16 \mathrm{~S} / 1999 / 516$.

17 The International Criminal Tribunal for the Former Yugoslavia, on 24 May 1999, indicted President Milosevic of the Federal Republic of Yugoslavia, and certain of his key allies, on charges which related to the deportation of 740,000 Kosovo Albanians and the murder of 340 others. Milosevic, the indictment alleges, was responsible for committing, planning, instigating, ordering and abetting war crimes and crimes against humanity, and, as the civilian leader of the military and police forces, for failing in his obligation to prevent those forces from committing atrocities: see, generally, Scharf, "The Indictment Of Slobodan Milosevic", June 1999: <www.asil.org/insigh35.htm>.

18 S/1999/649.

19 SC Res. 1244 (1999) at para. 1.

20 Ibid at para 2. This provision is significant given that international agreements concluded as a result of the use or threat of unlawful force are considered void ab initio: Fisheries Jurisdiction (Jurisdiction) Case ICJ Rep. 1973 14, and Article 52 of the Vienna Convention on the Law of Treaties 1969. The adoption of the agreement by the Security Council, in Resolution 1244, removes the possibility of the agreements between the Federal Republic of Yugoslavia and the international community being considered void, and therefore not binding on the Milosevic regime.

21 SC Res. 1244 (1999), preamble.

22 Ibid. at para. 11. 
and repression in Kosovo", ${ }^{23}$ and withdraw all its forces from the region. Moreover, to prevent the return of Serb forces, and to provide a secure environment in which refugees and displaced persons could return, an international security presence in Kosovo (K-FOR) was established. ${ }^{24}$ In respect of the second, an international civilian authority was established to provide interim governance for the region, "pending a final settlement, of substantial autonomy and self-government in Kosovo". ${ }^{25}$ No move is indicated towards the recognition of independence for Kosovo, ${ }^{26}$ and indeed Resolution 1244 does not contain the commitment to a referendum on the issue which was present in the Rambouillet accord.

\section{THE USE OF FORCE TO PREVENT HUMANITARIAN SUFFERING}

The military action undertaken by NATO was contentious to say the least, and opposed by certain States on the following bases: first, that the situation in Kosovo was an internal matter and not the concern of the United Nations, nor other States:27 secondly, even if the situation in Kosovo was the legitimate concern of the international community, under the Charter of the United Nations, intervention by a state, group of states, or international organisation, by military force is unlawful unless authorised by the Security Council - irrespective of the humanitarian objectives adduced. As to the first objection, that the situation in Kosovo was an internal matter, ${ }^{28}$ there is clear evidence that the obligation on states not to intervene in the internal affairs of other states is not applicable in instances of serious and widespread human rights abuses:

"Contemporary international law establishes beyond any doubt that serious violations of human rights are matters of international concern ... In the event of human rights violations which reach the magnitude of the Kosovo crisis, the developments in international law allow states, acting individually, collectively or though international organizations, to make use of a broad range of peaceful responses". ${ }^{29}$

23 Ibid. at para. 3.

24 Ibid. at para. 9.

25 Ibid. at para. 11 (a).

26 The Security Council reaffirms "the commitment of all Member States to the sovereignty and territorial integrity of the Federal Republic of Yugoslavia...": ibid., preamble.

27 "The question of Kosovo, as an internal matter of the [FRY], should be resolved among the parties concerned in the [FRY] themselves (Mr. Qin Huasun, China)": Security Council Debates, 24 March 1999, S/PV.3988.

The principle of non-intervention prohibits "dictatorial interference" (Oppenheim, International Law (1955, 8th ed.), p 305) in matters which "each state is permitted, by the principle of state sovereignty, to decide freely" (Nicaragua Case (Merits) ICJ Rep. 198614 at para 205). See, generally, Declaration on Principles of International Law Concerning Friendly Relations and Co-Operation Among States (1970), GA Resolution 2625 (XXV), adopted 24 October 1970; see, also, Verwey, supra n. 4, at 358 - 366.

28 This contention was rejected by a majority of States, and, interestingly, the Russian Federation did not make this argument. The dominant view was reflected in the remarks of the representative of the United States: "The actions of the $[F R Y]$... violate its commitments under the Helsinki Final Act, as well as its obligations under the international law human rights. Belgrade's actions in Kosovo cannot be dismissed as an internal matter", S/PV.3988.

29 Simma, "NATO, the UN and the Use of Force: Legal Aspects" (1999) 10 EJIL 1 at 1 - 2 (emphasis added). Indeed the initial response of European Govern- 
The NATO intervention was, however, self-evidently not peaceful, and appears, prima facie, to involve a serious violation of the Charter of the United Nations' prohibition on the use of force in inter-state relations. ${ }^{30}$ The Charter prohibits the use of military force "against the territorial integrity or political independence of any state, or in any other manner inconsistent with the purposes of the United Nations", ${ }^{31}$ and considers any intervention in violation of this provision to be an unlawful, aggressive, action. ${ }^{32}$ The only exceptions, explicitly provided by the Charter, ${ }^{33}$ are acts of individual or collective self-defence, ${ }^{34}$ which are not relevant to the situation considered here, ${ }^{35}$ and military action authorised by the Security Council, under the provisions on collective security.

ments to the Serb actions in Kosovo was to instigate a ban on all flights by Yugoslav carriers to EU States: (EC) Regulation 1901/98 concerning a ban on flights of Yugoslav carriers between the Federal Republic of Yugoslavia and the European Community OJL248/1, as amended by Regulation 214/99 OJL023/6.

30 Article 2(3), UN Charter.

31 Article 2(4). Interventions such as the one undertaken by NATO States may be contrasted with acts of 'humanitarian assistance': the provision of humanitarian aid, against the wishes of the sovereign state, on a small scale, to alleviate the suffering of persons. Whilst certain authors have suggested that acts of forcible humanitarian assistance should be subsumed under the general heading of humanitarian intervention (Gordon, "Humanitarian Intervention by the United Nations: Iraq, Somalia and Haiti” (1996) 31 Texas International Law Journal 43 at 45), they are best considered separately given that humanitarian intervention, proper, will inevitably involve a substantial encroachment of the sovereign rights of the target state, which may not be temporary in nature.

See, on the issue of humanitarian assistance: UK Foreign Office Memorandum to HC Foreign Affairs Committee, reprinted (1992) 63 BYIL 825; Nicaragua Case (Merits) ICJ Rep. 198614 at para 242; Article 59, (Fourth) Geneva Convention Relative to the Protection of Civilians in Time of War (1949); Cuny, "Dilemmas of Military Involvement in Humanitarian Relief ", in Gordenker and Weiss (eds.), Soldiers, Peacekeepers and Disasters (1991) 52; Helton, "The Legality of Providing Humanitarian Assistance Without the Consent of the Sovereign" (1992) 4 International Journal of Refugee Law 373 at 375; Arulpragasam, "International Agreements - Indo-Sri Lanka Agreement 1987" (1988) 29 Harv. Int'l Law Jnl 178; and, Chandrahasan, "Use of Force to Ensure Humanitarian Relief - A South Asian Precedent Examined" (1993) 42 ICLQ 664 .

32 United Nations General Assembly Resolution on the 'Definition of Aggression' 1974: GA Res. 3314 (XXIX), 14 December 1974.

33 See, generally, Schachter, "Authorized Uses of Force by the United Nations and Regional Organizations", in Damrosch and Scheffer (eds.), Law and Force in the New International Order (1992) 65.

34 Article 51: "Nothing in the present Charter shall impair the inherent right of individual or collective self-defence if an armed attack occurs against a Member of the United Nations, until the Security Council has taken measures necessary to maintain international peace and security".

$35 C f$. the position of the Balkan Action Council, which has argued that the Kosovar people's right of self-determination gives them a right of collective self-defence, and that the NATO intervention is justified under the right of collective self-defence under Article 51, UN Charter: Williams, "Legal Basis for NATO Military Action Taken Against Serbia/Montenegro", Balkan Action Council, 1 April 1999 (document on file with author); see, also Kirgis, "The 
The following sections consider, first, the role of the Security Council in the prevention of suffering to the human person, and secondly, whether NATO, as a mutual defence organisation, is able to defend the legality of its intervention in the Federal Republic of Yugoslavia by reference to the provisions on collective security in the Charter of the United Nations.

\section{THE SECURITY COUNCIL AND INTERVENTION TO PREVENT HUMANITARIAN SUFFERING}

One of the main criticisms levelled at the intervention by NATO States was that it had the effect of undermining the primacy of the Security Council, under the Charter of the United Nations, for the maintenance of international peace and security. ${ }^{36}$ Moreover, at a time following the ending of the Cold War, when the Security Council was beginning to fulfil the role envisaged for it under the Charter, the intervention was seen as creating a dangerous precedent for future actions which might seek to circumvent the requirements for undertaking enforcement action. ${ }^{37}$ If military force were to be employed, it was argued, it must, under the Charter, be authorised by the Security Council, either under the provisions of Chapter VII ${ }^{38}$ or under Chapter VIII, if the action was to be carried out by a regional arrangement or agency, as in this case. ${ }^{39}$

The Security Council is, however, unable to authorise the use of military force for humanitarian reasons simpliciter. Under the Charter of the United Nations, the Council may only authorise military intervention where it has determined that a given situation threatens international peace and security. ${ }^{40}$ In the absence of such a determination, Security Council

Kosovo Situation and NATO Military Action": <www.asil.org/insigh30.htm>; Verwey, supra n. 4, at 397 - 8; also Pomerance, Self-Determination in Law and Practice: The New Doctrine in the United Nations (1982), p 49).

It may also be possible to argue that those States (Albania and Macedonia) which suffered an influx of refugees, as a result of the actions of the Yugoslav authorities, could consider themselves subject to an 'armed attack' for the purposes of Article 51, and thus possessing an individual and collective right of self-defence. This argument would not find general support.

36 "[Under Article 24 (1) of the Charter] it is the Security Council that bears primary responsibility for the maintenance of the international peace and security. And it is only the Security Council that can determine whether a given situation threatens international peace and security and can take appropriate action...(Mr. Qin Huasun, China)": S/PV.3988.

37 "If we do not put an end to this very dangerous trend, the virus of illegal unilateral approaches could spread not merely to other geographical regions but to spheres of international relations other than questions of peace and security" (Mr. Lavrov, Russian Federation)": S/PV.3988.

38 Article 42, UN Charter.

39 Article 53, UN Charter. It is generally considered, under the Charter, that individual states, even acting collectively, are not permitted to undertake enforcement action without Security Council approval: Certain Expenses of the United Nations Case [1962] ICJ Rep. 151.

40 Article 39, UN Charter. Whilst Article 39 grants the Council a wide discretion as to the situations in which it may become involved, that discretion is not "totally unfettered" (Prosecutor v Tadic (Jurisdiction) (1996) 35 ILM 35 at para. 29), and there must, in fact, exist a "threat to international peace and security". $C f$. Fifoot, "Functions and Powers, and Interventions: UN Action in Respect of Human Rights and Humanitarian Intervention", in Rodley (ed.) To Loose the Bands of Wickedness: International Intervention in Defence of 
involvement is precluded by Article 2(7) of the Charter, ${ }^{41}$ and whilst violations of human rights, and humanitarian catastrophes, may entail a threat to international peace and security, they do not necessarily do so. ${ }^{42}$ Significantly, in its resolutions on Kosovo, ${ }^{43}$ the Security Council found that the deteriorating humanitarian situation did create a threat to peace and security, ${ }^{44}$ and in Resolution 1199 demanded that all parties to the conflict "immediately cease hostilities"; that the authorities in the Federal Republic of Yugoslavia, and the Kosovan Albanian leadership, "take immediate steps to improve the humanitarian situation and avert the impending humanitarian catastrophe"; and that the parties "negotiate a political solution". Resolution 1199 did not, however, authorise the use of force, but determined that "should the concrete measures demanded in this Resolution ... . not be taken, [the Security Council would] consider further action and additional measures to maintain or restore peace and stability in the region". 45

Human Rights (1992) 133, at 153. This limitation, on the right of the Security Council to intervene in situations where the rights of the human person are being violated, has not provided, in practice, an insurmountable encumbrance to Council intervention. An examination of the practice of the Security Council evidences a clear willingness, on its part, to authorise the use of force in circumstances where it is not obvious that a threat to international peace and security exists, most notably in the case of Somalia, where the Council responded to the "the magnitude of the human tragedy": Security Council Resolution 794 (1992). See, generally, Hutchinson, "Restoring Hope: UN Security Council Resolutions For Somalia and an Expanded Doctrine of Humanitarian Intervention" (1993) 34 Harv. International Law Jnl 624; Lewis and Mayall, "Somalia", in Mayall (ed.), The New Interventionism: 1991-1994 (1996), p 94. See, also resolutions in respect of Albania (SC Res. 1101 (1997)); Haiti (SC Res. 917 (1994), SC Res. 940 (1994)); Rwanda (SC Res. 918 (1994), SC Res. 929 (1994)); and Sierra Leone (SC Res. 1132 (1997)).

41 See Delbrück, "A Fresh Look at Humanitarian Intervention Under the Authority of the United Nations" (1992) 67 Indian Law Jnl 887 at 891 - 896.

42 Higgins, "International Law in a Changing International System" (1999) 58 Cambridge Law Journal 78 at 95. The Security Council is, however, demonstrating an increased willingness to declare a threat to peace and security in circumstances where it is not clear, beyond the "widespread and flagrant violations of international humanitarian and human rights law" (SC Res. 1264 (1999)), that a threat to peace and security exists. Resolution 1264, establishing a multinational force, empowered to take all necessary means, to restore peace and security in East Timor, to protect and support the United Nations Mission in East Timor (UNAMET) and to facilitate humanitarian assistance operations, refers only to the worsening humanitarian conditions in East Timor and consequential impact on the civilian population and UN personnel; it does not indicate that any wider threat to peace and security exists.

43 See SC Res. 1160 (1998), SC Res. 1199 (1998) and SC Res. 1203 (1998).

44 The Council was particularly concerned with the "excessive and indiscriminate use of force by Serbian security forces", the displacement of an estimated 230,000 persons and the flow of refugees into neighbouring countries, the "rapid deterioration of the humanitarian situation ... [and] impending humanitarian catastrophe", and reports of "increasing violations of human rights and of international humanitarian law": SC Res. 1199 (1998).

45 SC Res. 1199, at para. 16. The reasoning behind this refusal was the anticipated Chinese and Russian opposition to any attempt to authorise enforcement action against the Federal Republic of Yugoslavia. See, Youngs, "Kosovo: The 
The adoption, by the Security Council, of a number of resolutions on Kosovo - and the Federal Republic of Yugoslavia's failure to comply with them - provided, in the view of a number of States, a certain degree of legitimacy for the NATO intervention, ${ }^{46}$ and de facto limits on its extent $;{ }^{47}$ the resolutions could not, however, provide any lawful authority for the intervention in the Federal Republic of Yugoslavia, given the absence of any express authorisation from the Council for the use of military force. ${ }^{48}$ This absence of express authorisation did not, though, according to NATO States, create a categorical impediment to determining that military force could be employed in the circumstances: ${ }^{49}$

"It goes without saying that a country - or an alliance - which is compelled to take up arms to avert such a humanitarian catastrophe would always prefer to be able to base its action on a specific Security Council resolution ... If If, however, due to one or two permanent members' rigid interpretation of the concept of domestic jurisdiction, such a resolution is not attainable, we cannot sit back and simply let the humanitarian catastrophe occur...". (Mr. Van Walsum, Netherlands)..$^{50}$

NATO States clearly believed they enjoyed sufficient legal authority for the intervention without the express authorisation of the Security Council. A claim of legality does not, however, make the intervention lawful; we must consider both the collective nature of the intervention, and the relevance of arguments that would permit unilateral intervention to prevent a humanitarian catastrophe, or human rights violations.

Diplomatic and Military Options", HC Paper 98/93 (1998), fns 25 - 7, and accompanying text. See, also, The Guardian, 29 January 1999.

46 See, in particular, the views of Mr. Burleigh (United States of America); Mr. Fowler (Canada); and Mr. Dejammet (France): S/PV.3988.

47 "It is our expectation and belief that the action which is being undertaken will be carried out strictly within the substantive parameters established by the relevant Security Council resolutions (Mr. Türk, Slovenia)": S/PV.3988 (emphasis added).

48 A state may not rely on resolutions adopted by the Security Council which do not explicitly authorise the use of force to justify military intervention. See, for example, US and UK air strikes against Iraq, 16-20 December 1998, in response to the latter's failure to comply with Security Council Resolution 1154 (SC Res. 1154 (1998)). Whilst the resolution had threatened the "severest consequences" if Iraq did not comply with its demands, it could not be viewed as providing sufficient authority for the attacks. France, China and Russia, the other permanent members of the Security Council, argued that a further resolution was required prior to any attack: (1998) Keesings Record of World Events 42697-42700. See, Kirgis, "The Legal Background on the Use of Force to Induce Iraq to Comply with Security Council Resolutions" (1997): $<$ http://www.asil.org/insigh12.htm>.

49 "There may be a moment in which it is necessary to act for humanitarian reasons, when a UN Security Council resolution will not be necessary or will not even be appropriate because the UN Charter does not contemplate humanitarian acts (NATO Secretary-General Solana)": Financial Times (London), 9 October 1998.

50 See, also the views of Mr. Türk (Slovenia), and Mr. Hasmy (Malaysia): S/PV.3988. 


\section{COLLECTIVE INTERVENTION UNDER THE CHARTER OF THE UNITED NATIONS}

A role for international organisations, other than the United Nations, in the maintenance of international peace and security, is provided for by Chapter VIII of the Charter of the United Nations, which requires that "regional arrangements or agencies" make every effort to deal with an issue which threatens international peace and security before referring the matter to the Security Council. ${ }^{51}$ The Security Council is directed to utilise such arrangements where appropriate, although enforcement action by a regional arrangement or agency may not be undertaken "without the authorization of the Security Council". ${ }^{52}$ There are two issues for our consideration: first, whether NATO may be considered an appropriate regional arrangement or agency under Chapter VIII, and secondly, the relevance of Chapter VIII of the Charter, given the absence of explicit Security Council authorisation for the intervention.

Whilst the United Nations' Charter recognises, and indeed legitimates, the existence of regional arrangements or agencies, it provides no definition as to which international entities will constitute such an organisation, ${ }^{53}$ although in An Agenda for Peace, the (then) Secretary-General argued for an inclusive understanding of the concept, extending to those "groups created to deal with a specific political, economic or social issue of current concern".${ }^{54}$ In the present case, we are faced with the further difficulty that NATO was not established as a regional arrangement or agency, ${ }^{55}$ but, under the North Atlantic Treaty (1949), as a mutual assistance organisation, guaranteeing collective defence in the event of a military attack on a member State from a non-member. ${ }^{56}$ Does the organisation, then, enjoy the right to undertake an armed intervention outside the territory of its members, or is such action to be considered ultra vires to the organisation's own objectives and Charter. In response, it might be noted that there appear to be few difficulties in accepting the right of member States to alter the nature of an organisation which, like NATO, reaches its decisions by consensus, "as long as all members agree", ${ }^{57}$ more significantly, perhaps, in the particular case of NATO, the organisation has been undertaking such a role "uncontroversially under a direct UN mandate in Bosnia since 1995". ${ }^{58}$

51 Article 52 (2), UN Charter.

52 Article 53(1).

53 Article 52 (1).

54 Boutros Boutros-Ghali, An Agenda for Peace (1992) SC Doc. S/24111, 17 June 1992.

55 Higgins, supra n. 42, at 93.

56 "[A]n armed attack against one or more [member State(s)] ... shall be considered an attack against them all and consequently they agree that, if such an armed attack occurs, each of them, in exercise of the right of individual or collective self-defence . . . will assist the Party . . . so attacked", North Atlantic Treaty (1949), Article 5. Moreover, NATO recognises the "primary responsibility of the Security Council for the maintenance of international peace and security", ibid., Article 7.

57 Simma, supra n. 29, at 19.

58 Weller, "UN Accepts That Humanitarian Ends Justify Military Means", The Times (London) 25 March 1999. Security Council Resolution 816 (1993) authorised NATO to shoot down aircraft violating the no-fly zone over Bosnian airspace (which NATO aircraft did in cases where the airspace was violated). 
Even if, however, NATO may be considered a regional arrangement or agency for these purposes, the intervention in the Federal Republic of Yugoslavia was not expressly authorised by the Security Council, and the Charter of the United Nations "clearly stipulates that no enforcement actions shall be undertaken under regional arrangements without the authorization of the ... Council". ${ }^{59}$ Is such authorisation, though, required to be explicit, or indeed provided prior to any intervention; could it not be provided ex post facto or be implied by the Council's behaviour? Whilst such a "less-than-rigorous" 60 interpretation of the Charter may provide some legal basis for certain interventions, in the present case, it is clear that the opposition of China and Russia to any military intervention in the Federal Republic of Yugoslavia (over which they would have a veto, were the issue to come before the Council) would preclude us accepting that the action was authorised, even on a less than rigorous interpretation.

\section{CASE CONCERNING LEGALITY OF USE OF FORCE}

During the air campaign, the Federal Republic of Yugoslavia filed ten separate applications, simultaneously, against, respectively, Belgium, Canada, France, Germany, Italy, the Netherlands, Portugal, Spain, the United Kingdom, and the United States, with the International Court of Justice (Case Concerning Legality of Use of Force), requesting that the Court indicate the following measure:

"[The respondent State] shall cease immediately its acts of use of force and shall refrain from any act of threat or use of force against the Federal Republic of Yugoslavia".

Whilst the jurisdictional issues were not the same in each case - indeed the Court dealt with them separately - the substantive issues were: the Federal Republic of Yugoslavia alleged that the NATO action constituted a violation of Article 2(4) of the Charter of the United Nations, which could not be justified by reference to self-defence or relevant Security Council resolution; nor could it be justified by reference to any doctrine of humanitarian intervention, which enjoyed no legal validity. ${ }^{61}$

The Federal Republic of Yugoslavia further alleged that not only did the means by which the air campaign was conducted violate international law, ${ }^{62}$ but that the nature of the action, in particular the massive environmental damage caused and the use of depleted uranium in NATO weapons, violated the obligation incumbent upon states not to deliberately

See, generally, Woodliffe, "The Evolution of a New NATO for a New Europe" (1998) 47 ICLQ 174 at $183-187$.

59 Mr. Sharma (India): S/PV.3988.

60 Murphy, supra n. 5, at 346.

61 See Oral Pleadings, Case Concerning Legality Use of Force, 10 May 1999: <www.icj-cij.org>.

62 The Federal Republic of Yugoslavia alleged breaches of international obligations to spare the civilian population; not to commit any act of hostility against historical monuments or places of worship; not to use weapons (that is, cluster bombs) which cause unnecessary suffering; not to cause considerable environmental damage (in the bombing of oil refineries and chemical plants); not to use prohibited weapons or cause far reaching environmental damage (in the use of weapons containing depleted uranium); to respect the right of civilian persons to life, and to other human rights; and to respect freedom of navigation on international rivers (through the destruction of bridges): see, for example, Case Concerning Legality Use of Force (Yugoslavia v Canada) at para. 4, (1999) 38 ILM 1037. 
inflict on a national group conditions of life calculated to bring about its physical destruction, in whole or part; that is, the Federal Republic contended that the military intervention by NATO States constituted a violation of the Convention on the Prevention and Punishment of the Crime of Genocide (1948). To some extent the allegation must be seen as 'procedural', given that it presented the Federal Republic with an alternate basis, under Article IX of the Genocide Convention, upon which to argue that the International Court enjoyed jurisdiction, ${ }^{63}$ to that provided under the Statute of the Court itself. ${ }^{6}$

In its decision, on the issue of jurisdiction, the Court declared itself "deeply concerned with the human tragedy, the loss of life, and the enormous suffering in Kosovo ... and with the continuing loss of life and human suffering in all parts of Yugoslavia", 65 and emphasised the requirement that "all parties appearing before it must act in conformity with their obligations under the Charter of the United Nations and other rules of international law, including humanitarian law . . "66 The International Court concluded, however, that it lacked prima facie jurisdiction to consider the application, and could not, as a consequence, indicate the provisional measures requested by the Federal Republic of Yugoslavia. ${ }^{6}$

In reaching its decision, the Court determined that the threat or use of force against a state could not, in itself, constitute an act of genocide, within the meaning of Article II of the Genocide Convention; nor could

63 In relation to Spain and the United States, the Court determined that reservations entered, by the respective states, to Article IX of the Genocide Convention, precluded the Court exercising jurisdiction. The cases filed against Spain and the United States were removed from the Court's docket. The cases against the remaining eight States were ordered to remain, in relation to the accusation of genocide only; see infra $\mathrm{n}$. 67 (and accompanying text).

64 As against Belgium, Canada, the Netherlands, Portugal, Spain and the United Kingdom, the Federal Republic of Yugoslavia attempted to rely upon Article 36(2), Statute of the International Court of Justice: "The state parties to the present Statute may at any time declare that they recognise as compulsory ipso facto and without special agreement, in relation to any other states accepting the same obligation, the jurisdiction of the Court in all legal disputes..."; in respect of France, Germany, Italy and the United States, the application by Yugoslavia was transmitted to the States named as respondent, under Article 38 (5) of the ICJ's Rules of Court. However, as none of the States involved indicated that it accepted the Court's jurisdiction, the Court could not exercise jurisdiction. See, generally, Case(s) Concerning Legality Use of Force: (1999) 38 ILM 950; also, Bekker and Borgen, "World Court Rejects Yugoslav Requests to Enjoin Ten NATO Members from Bombing Yugoslavia", June 1999: 〈www.asil.org/insigh36.htm>.

As against Belgium, Yugoslavia's attempt to rely on Article 4 of the Convention of Conciliation, Judicial Settlement and Arbitration between the Kingdom of Yugoslavia and Belgium (1930) was rejected by the Court, given that it had not been introduced until the second round of oral argument on a request for the indication of provisional measures: Case Concerning Legality Use of Force (Yugoslavia - v - Belgium) at para. 44: (1999) 38 ILM 950.

65 See, for example, Case Concerning Legality Use of Force (Yugoslavia v Canada) Request for the Indication of Provisional Measures at para. 15, (1999) 38 ILM 1037 (emphasis added).

66 Ibid. at para. 18.

67 Ibid. at para. 29 and 40. 
the bombings which formed the subject of the application be considered to "entail the element of intent ... required by [Article II of the Genocide Convention]".68 Furthermore, it could not be demonstrated that the jurisdiction of the Court had been accepted by all parties. Most significantly, the Federal Republic of Yugoslavia, had not accepted the compulsory jurisdiction of the Court, under Article 36(2) of the Court's Statute, until 26 April 1999. Given that the bombings had commenced prior to that date, on 24 March 1999, and had continued, without interruption, beyond the time of the acceptance, by the Federal Republic, of the Court's compulsory jurisdiction, the International Court of Justice considered that the legal dispute before it predated the acceptance, by all parties, of its jurisdiction. ${ }^{69}$

We must, then, examine the legality of the intervention by NATO States without the benefit of a determination by the International Court of Justice of certain of the principal legal issues involved.

\section{THE LEGALITY OF THE NATO INTERVENTION}

Examination of the provisions on the use of military force under the Charter of the United Nations has demonstrated that NATO is unable to justify its action by reference to the provisions on collective security, under Chapter VII and VIII of the Charter, or, as we have noted, by reference to the provisions on self-defence. Whilst there may be advantages to be gained, therefore, in undertaking an intervention under the auspices of a de facto collective security organisation, viz. NATO, rather than unilaterally - notably a greater perception of "impartiality and evenhandedness" 70 - NATO States will not enjoy any right of intervention collectively beyond that which they enjoy individually. ${ }^{71}$ The intervention may only be considered lawful if each State acted according to a right of intervention which it enjoyed itself. Consequently, we must examine first, whether a general right of intervention to prevent a humanitarian catastrophe exists, under the Charter of the United Nations and general international law, ${ }^{72}$ as an exception to the prohibition on aggressive intervention; ${ }^{73}$ and, secondly, if such a right does exist, whether the NATO intervention may be considered a legitimate exercise of such a right. ${ }^{74}$

68 Ibid. at para. 39.

${ }^{69}$ Ibid. at para. 41. See, however, the strong dissent of Vice-President Weeramantry.

70 Murphy, supra n. 5, at 336.

71 “. . . [N]o unanimity of NATO members can do away with the limits to which these states are subject under peremptory international law (jus cogens) outside the organization, in particular the higher law ( $c f$. Article 103) of the UN Charter on the threat or use of armed force": Simma, supra n. 29.

72 See, generally, on this Verwey, supra n 4, at 378 - 388.

73 In order to answer this question, we must accept that there is no lacuna, or non liquet, on this point of international law: Aznar-Gómez, "The 1996 Nuclear Weapons Advisory Opinion and Non Liquet in International Law" (1999) 48 ICLQ 3 .

$74 C f$. "[T]hree sets of values underpin the overarching system of inter-state relations: peace, human rights and self-determination. However, any time that conflict or tension arises between two or more of these values, peace must always constitute the ultimate and prevailing factor": Cassese, "Ex iniuria ius oritur: Are we moving towards international legitimation of forcible humanitarian countermeasures in the world community?" (1999) 10 EJIL 23 at 24. See, also, Little, "Recent Literature on Intervention and Non-intervention", 


\section{HUMANITARIAN INTERVENTION}

Prior to the adoption of the Charter of the United Nations, in the nineteenth and early twentieth century, the legitimacy of interventions such as that carried out by NATO States against the Federal Republic of Yugoslavia was considered by reference to the doctrine of humanitarian intervention. This right of intervention was invoked by States who sought to legitimise military action whose stated purpose was to put an end to atrocities being committed against a local population by the governing authorities ${ }^{75}$ (in particular, in circumstances where the local population was under "alien" or "colonial" rule ${ }^{76}$ ). Whilst it is accepted that most instances of humanitarian intervention in this period were not genuine, ${ }^{77}$ a right to intervene was recognised in response to atrocities which "shock[ed] the conscience of mankind", ${ }^{78}$ reflecting an acceptance of universal principles of decency and humanity, ${ }^{79}$ and limits on the "authority within which the sovereign [State] is presumed to act with reason and justice" 80

There has been much discussion as to whether a right of humanitarian intervention survived the adoption of the Charter of the United Nations, although it is generally accepted, if it did, that, in its present formulation, humanitarian intervention involves:

"the protection of fundamental human rights by a State or group of States . .. [through] the use or threat of force, [without] authorization by relevant organs of the United Nations nor upon invitation by the legitimate government of the [target] State". 81

in Forbes and Hoffman, Political Theory, Intervention Relations and the Ethics of Intervention (1993) 13, at 21.

75 "Until 1945, there was no customary international prohibition on the unilateral resort to force": Reisman, "Coercion and self-determination: Construing Charter Article 2(4)" (1984) 78 AJIL 642 at 642. This absence of a general prohibition has not, however, prevented authors considering the 'justness', or 'legitimacy', of interventions: Meron, "Common Rights of Mankind in Gentili, Grotius and Suárez" (1991) 85 AJIL 110.

76 Specifically, Christian populations under the authority of the Ottoman Empire. See, for example, interventions in Greece (1827 - 1830), Syria (1860 -1861), Crete (1866 - 1868), Bosnia, Herzegovina, and Bulgaria (1876 - 1878), and Macedonia (1903 - 1908, 1912 - 1913): Fonteyne, supra n. 5, at 207 - 214.

77 For a review of the literature on this point, see Donnelly, "Human Rights, Humanitarian Intervention and American Foreign Policy" (1984) 37 Journal of International Affairs 311, at 314 - 317; see, also, Pogany's examination of one of the alleged 'humanitarian' interventions: "Humanitarian Intervention in International Law, The French Intervention In Syria Re-Examined" (1986) 35 ICLQ 45 .

78 “. . . when a State renders itself guilty of cruelties against and persecution of its nationals in such a way as to deny their fundamental human rights and to shock the conscience of mankind, intervention in the interest of humanity is legally permissible. . .": Oppenheim, International Law (1955, 8 ${ }^{\text {th }}$. ed.), p 312 (emphasis added).

79 Stowell, Intervention in International Law (1921), p 51.

${ }^{80}$ Ibid., p 53.

81 Verwey, supra n. 4, at 375 . This understanding excludes military intervention to rescue nationals held abroad (Asrat, Prohibition of Force Under the UN Charter: A Study of Art. 2(4) (1991), p 184-5), although not all writers accept 
Humanitarian intervention, then, provides a remedy of last resort in cases of serious and widespread abuses of the civil and political human rights. ${ }^{82}$ There are, though, a number of difficulties with this approach, beyond the need to distinguish "tolerable [human rights] abuses from intolerable ones" ${ }^{83}$ given that not every violation of a human right, even the right to life, could justify military intervention.

First, beyond the initial consensus that humanitarian intervention involves the use of force to prevent the violation of fundamental human rights, there is little agreement as to which particular human rights, if violated, will justify intervention: ${ }^{84}$ different writers have referred, inter alia, to the

such a distinction: Pease and Forsythe, Human Rights, Humanitarian Intervention, and World Politics (1993), p 298; Schachter, "The Right of States to Use Armed Force" (1984) 82 Michigan Law Review 1620 at 1628 - 1633. Rescue missions are properly considered as examples of self-help (Fonteyne, "Forcible Self-Help by States to Protect Human Rights: Recent Views from the United Nations", in Lillich (ed.) Humanitarian Intervention and the United Nations (1973) 197, p 199), or self-defence (Nash, "Contemporary Practice of the United States Relating to International Law" (1979) 73 AJIL 122 at 124). This may be contrasted with humanitarian interventions, which may be considered, broadly, altruistic in nature. The United Kingdom Foreign Office considers them separately: Memorandum submitted by the Foreign and Commonwealth Office, "Kosovo: Legal Authority for Military Action", HC $118-i$, at paras. 4 and 5 .

This inquiry excludes from its consideration, then, as 'rescue missions': the Belgian and American interventions in the Congo (1960 and 1963); the initial phase of the United States intervention in the Dominican Republic (1965); and the Belgian and French intervention in Zaire (1978). On the legality of such interventions, see Jeffrey, "The American Hostages in Tehran: The ICJ and the Legality of Rescue Missions" (1981) 30 ICLQ 717.

82 A doctrine of 'human rights' intervention must be conceptually grounded in a view that sovereign rights are conditional upon a minimum respect for civil and political rights. There are a number of difficulties in this approach: first, it reflects the values of the occident, rejecting the pre-eminent concern of other states for respect for their sovereign independence (Kausikan, "Asia's Different Standard" (1993) 92 Foreign Affairs 24). Secondly, it ignores the fact that all human rights, including economic, social and cultural rights, are considered universal, indivisible, interdependent and interrelated and to be treated "on the same footing and with the same emphasis": World Declaration on Human Rights - The Vienna Declaration and Programme of Action (1993) at para 5. A doctrine of humanitarian intervention which, however, recognised the equal validity of civil and political rights and economic, social and cultural rights would be unable to distinguish between the NATO intervention in Kosovo and the intervention by Soviet forces, in 1968, to end the 'Prague spring' in Czechoslovakia: see, Laberge, "Humanitarian Intervention: Three Ethical Positions" (1995) 9 Ethics and International Affairs 15 at 21 - 22.

83 Laberge, ibid., at 28; One contemporary approach argues that intervention by the United States should only be undertaken where the death rate in the target state, as a result of the relevant conflict, exceeds the murder rate in the US: Solarz and O'Hanlon, Washington Post, 7 February 1999.

84 'References are found to 'gross', 'massive', 'large-scale' or 'persistent' violations, of 'elementary' or 'fundamental' human rights, in such a way that 'atrocities', 'barbaric acts' or 'repulsive practices' are committed, which constitute 'crimes against (the laws of) humanity' or 'genocide', and are considered to 'shock the conscience of mankind' or 'flagrantly violate standards of 
right to life, ${ }^{85}$ in particular if violated on a massive scale; ${ }^{86}$ acts of genocide, slavery or widespread torture; 87 and the arbitrary and systematic nature in which abuses are committed. ${ }^{8}$ Given, however, that most human rights may be subject to certain restrictions in times of internal conflict or public emergency, 89 a right of intervention could only exist where the human rights violated could be considered both universal and fundamental, ${ }^{90}$ with, according to Verwey, the right to life standing out "as the most prominent and undisputed human right protectable by humanitarian intervention" ${ }^{91}$ Even this 'minimalistic' grounding of a right of humanitarian intervention is not, though, without difficulties: the right to life is not absolute; ${ }^{92}$ further, in circumstances where an internal armed conflict exists, as in Kosovo, a determination as to whether a particular loss of life amounts to a violation of the human right to life requires consideration of the applicable law of armed conflict, ${ }^{93}$ with the intervening State required to demonstrate a violation of the jus in bello, as a precondition to finding a violation of the right to life, to justify its intervention. ${ }^{94}$

A second difficulty in grounding a right of intervention in the violation of human rights is the requirement that the intervening State demonstrate a legal interest in the human rights violations in question. In our particular case, whilst the Federal Republic of Yugoslavia is party to a number of human rights treaties, ${ }^{95}$ its obligation to comply with the relevant

morality and civilization' singly or in combination of most definitions of humanitarian intervention": Verwey, supra n 4, at 368 - 369 (footnotes omitted).

85 Verwey, "Humanitarian Intervention", in Cassese (ed.), The Current Regulation of the Use of Force (1986) 57, p 59.

86 Bazyler, "Reexamining the Doctrine of Humanitarian Intervention in the Light of Atrocities in Kampuchea and Ethiopia" (1987) 23 Stanford Journal of International Law 547 at 598-601.

87 D'Amato, International Law: Process and Prospect (1987), p 226.

88 Donnelly, supra n. 77, at 313.

89 See Human Rights Committee General Comment 5, Article 4 of the International Covenant on Civil and Political Rights, (Thirteenth session, 1981), U.N. Doc. HRIIGEN\1\Rev.1 at 5 (1994).

90 Verwey, supra n. 4, at 410.

91 Ibid, at 369.

92 See, for example, Article 2(2), European Convention on Human Rights (1950).

93 Legality of the Threat or Use of Nuclear Weapons Case ICJ Rep. 199690 at para 25.

94 Common Article 3 of the Geneva Conventions of 1949: (First) Geneva Convention for the Amelioration of the Condition of Wounded and Sick in Armed Forces in the Field; (Second) Geneva Convention for the Amelioration of the Condition of Wounded, Sick and Shipwrecked Members of Armed Forces at Sea; (Third) Geneva Convention Relative to the Treatment of Prisoners of War; (Fourth) Geneva Convention Relative to the Protection of Civilians in Time of War. See, also, 1977 Protocol Additional to the Geneva Conventions of 12 August 1949, Relating to the Protection of Victims of NonInternational Armed Conflicts (Protocol II).

95 These include, inter alia, the Convention for the Prohibition and Punishment of the Crime of Genocide (1948), Convention Against Torture and Other Cruel Inhuman or Degrading Treatment or Punishment (1984), the International Convention on the Elimination of All Forms of Racial Discrimination (1966), the International Covenant on Civil and Political Rights (1966), and the Framework Convention on National Minorities (1994). 
international norms is owed to the other parties, and the appropriate international institution to the relevant covenant - not third states. ${ }^{96}$ Further, the other State parties are required to utilise the mechanisms established by the treaty in cases of alleged violation. ${ }^{97}$ Consequently, intervening states, to justify a general right of intervention, must rely on evidence of violations of human rights obligations owed erga omnes, ${ }^{88}$ in whose protection all States, as members of the international community, enjoy a legal interest. It is, though, difficult to identify specific human rights norms of erga omnes character; moreover, the international community has proved reluctant to allow individual states to enforce obligations owed to the collective, ${ }^{99}$ and, in any case, the International Court of Justice, in the Nicaragua Case, determined that "...the use of force could not be the appropriate method to monitor or ensure [respect for human rights]". ${ }^{100}$

These difficulties notwithstanding, the paradigmatic exposition of humanitarian intervention, as the protection of fundamental human rights through the use of military force, abides. Yet, despite a clear recognition that human rights were violated on a massive scale in Kosovo, ${ }^{101}$ NATO States did not seek to ground their right of intervention in those human rights violations. ${ }^{102}$ This has not, however, prevented attempts to analyse the intervention by reference to the previous understanding of humanitarian intervention, as intervention to protect human rights. Simma, for example, referring to a letter from NATO Secretary-General Solana, addressed to the permanent representatives of the North Atlantic Council argues that NATO justified its intervention by reference to the Federal Republic of Yugoslavia's refusal to "desist from further massive violations of human rights". ${ }^{103}$ Yet, the letter cited does not mention the violation of human rights in Kosovo, nor the need for intervention to prevent further violations. ${ }^{104}$ Unless we "discount what States actually said

96 S.W. Africa Cases (Preliminary Objections) (Ethiopia and Liberia v South Africa) ICJ Rep. 1962319.

97 In cases of alleged violations of human rights standards which arise as a result of membership of an international organisation, such as the United Nations, only the organisation, and not individual member states, is empowered to monitor implementation. (In this case, the Federal Republic of Yugoslavia is not a recognised member of a relevant international organisation.) However, whilst the Charter of the United Nations, for example, requires respect for human rights, it "does not permit enforcement to ensure it": Higgins, supra n. 42 , at 95.

98 See, Verwey, supra n. 4, at 374.

99 South West Africa Cases, Second Phase ICJ Rep. 19666.

100 Nicaragua Case (Merits) ICJ Rep. 198614 at para 268.

101 The UN Secretary General commented, "I am outraged by reports of mass killings of civilians in Kosovo": Report of The Secretary-General Prepared Pursuant To Resolutions 1160 (1998) And 1199 (1998) of The Security Council, S/1998/912, 3 October 1998 at para. 9.

102 Human rights violations are mentioned, briefly, by only two states in the Security Council debates on Kosovo: "What is at stake today is peace, peace in Europe - but human rights are also at stake": Mr. Dejammet (France); "The international community is facing a situation in which a Government in the heart of Europe is flouting the most fundamental rights of its citizens. . .": Mr. Fowler (Canada): S/PV.3988.

103 Simma, supra $\mathrm{n} 29$, at 12.

104 The letter refers to the need for the FRY to comply with relevant Security Council resolutions; the danger of a humanitarian disaster; the continuation of 
and rely on [our] own re-interpretation of the State practice", ${ }^{105}$ we cannot consider the intervention by NATO States by reference to any right of intervention to protect human rights: the legality of the action may only be judged in the light of the justification adduced.

\section{INTERVENTION TO PREVENT A HUMANITARIAN CATASTROPHE}

Following initial confusion, ${ }^{106}$ a clear and consistent justification as to the legal basis for the intervention by NATO States in the Federal Republic of Yugoslavia emerged: ${ }^{107}$ the use of military force was permissible where force was the only method by which the intervening states were able "to avert a humanitarian catastrophe". ${ }^{108}$ Is then humanitarian intervention the appropriate nomenclature for the action. Given the reliance, by the United Kingdom, on the "customary international law principle of humanitarian intervention" 109 to justify intervention on humanitarian grounds in Iraq, we should not preclude reference to it in this context - although we should recognise that humanitarian intervention involves, in this context, military intervention to prevent a humanitarian catastrophe, not the violation of fundamental human rights (although that will be one outcome of the intervention). This reconstituted understanding of humanitarian intervention is clearly controversial given the previous, human rights based, consensus. It does, though, accord with relevant state practice (viz. interventions in Liberia, Iraq and the Federal Republic of Yugoslavia), where a right of intervention has not been grounded in the manifest and serious violations of human rights.

\section{THE DEBATES IN THE SECURITY COUNCIL}

In the debates, in the Security Council, which followed the intervention in the Federal Republic of Yugoslavia, the representative of the United Kingdom, Sir Jeremy Greenstock, made the following assertion:

"The [NATO] action taken is legal. It is justified as a exceptional measure to prevent an overwhelming humanitarian catastrophe . . . Every means

the humanitarian catastrophe; the fact that the Security Council is unlikely to act; and the threat to regional peace and security. (Letter from SecretaryGeneral Solana, addressed to the permanent representatives to the North Atlantic Council, dated 9 October 1998): see, Simma, supra n. 29, at 7.

105 Gray, "After the Ceasefire: Iraq, the Security Council and the Use of Force" (1992) 65 BYIL 135 at 163.

106 Initially, NATO States sought to justify their action by reference to relevant Security Council resolutions: Meeting of the North Atlantic Council in Foreign Ministers Session, "Statement on Kosovo": Press Communiqué M-NAC-2(98) 143, 8 December 1998.

107 Foreign Secretary Cook, Evidence to Foreign Affairs Select Committee, 22 February 1999, HC 188 - ii: "The legal basis for our action is that the international community of states do have the right to use force in the case of overwhelming humanitarian necessity... [A]ll the legal advisors to the 19 Member States in NATO have come to the same conclusion" (emphasis added).

108 Memorandum submitted by the Foreign and Commonwealth Office, "Kosovo: Legal Authority for Military Action" at para. 5 (emphasis added): HC 118-i.

109 Aust, Legal Counsellor, FCO, evidence to House of Commons Select Committee, reprinted "UK Materials in International Law" (1992) 63 BYIL 827. 
short of force has been tried to avert this situation. In these circumstances, and as a exceptional measure on the grounds of overwhelming humanitarian necessity, military intervention is legally justified". 110

This argument was rejected by the Russian Federation: "Attempts to justify the NATO strikes with arguments about preventing a humanitarian catastrophe in Kosovo are completely untenable". ${ }^{111}$ This divergence of views is representative of those evidenced in the Security Council in its meeting of 24 March 1999: Albania, ${ }^{112}$ Bosnia and Herzegovina, ${ }^{113}$ Canada, France, Gambia, ${ }^{114}$ Malaysia, ${ }^{115}$ the Netherlands, the United Kingdom, and the United States supported the military action; whilst Argentina, ${ }^{116}$ Belarus, ${ }^{117}$ Brazil, ${ }^{118}$ China, Gabon, ${ }^{119}$ India, Namibia, ${ }^{120}$ the Russian Federation, and, naturally, the Federal Republic of Yugoslavia opposed it.

Significantly, however, two days later, a draft resolution, proposed by the Russian Federation, which condemned the NATO intervention as "a flagrant violation of the United Nations Charter" and demanded "an

110 S/PV.3988. See also the following:

[W] e believe that [the] action is necessary to respond to Belgrade's brutal persecution of Kosovar Albanians, violations of international law, excessive and indiscriminate use of force, refusal to negotiate to resolve the issue peacefully and recent military build-up in Kosovo - all of which foreshadow a humanitarian catastrophe of immense proportions (Mr. Burleigh, United States of America)....

NATO's objectives are to avert an ever widening humanitarian crisis... Humanitarian considerations underpin our action. We cannot simply stand by while innocents are murdered, an entire population is displaced, villages are burned and looted, and a population is denied its basic rights merely because the people concerned do not belong to the "right" ethnic group (Mr. Fowler, Canada).

111 S/PV.3988.

112 "The Republic of Albania totally supports the military action by [NATO]": Mr. Nesho (Albania).

113 "Military action is never a welcome option, but it is sometimes the best, the only alternative among many bad options. It may be the only option available to save innocent lives": Mr. Sacirbey (Bosnia and Herzegovina).

114 "It must be noted ... that at times the exigencies of a situation demand, and warrant, decisive and immediate action. We find that the present situation in Kosovo deserves such a treatment": Mr. Jagne (Gambia).

115 "We regret that in the absence of Council action on this issue it has been necessary for action to be taken outside of the Council": Mr. Hasmy (Malaysia):

116 "The attacks by [NATO] against Serb targets . . . are a source of great concern for Argentina": Mr. Petrella (Argentina).

117 "The President of Belarus issued earlier this morning a statement strongly denouncing the decision of [NATO] to use military strikes against a sovereign State": Mr. Martynov (Belarus).

118 "... . the Brazilian Government regrets that the escalation of tensions has resulted in recourse to military action": Mr. Enio Cordeiro (Brazil).

119 "My Government is in principle opposed to the use of force to settle local or international disputes": Mr. Dangue Réwaka (Gabon).

120 " $[\mathrm{M}] \mathrm{y}$ delegation appeals for the immediate cessation of the ongoing military action and for the exhausting of all possible avenues for a peaceful resolution of the conflict": Mr. Andjaba (Namibia). 
immediate cessation of the use of force against the Federal Republic of Yugoslavia", ${ }^{121}$ was defeated by twelve votes to three (China, Russia and Namibia), with no States abstaining. It is clear that, between the initial meeting on 24 March and that on 26 March, at which the Russian resolution was rejected, opinion had hardened amongst States on the need for action to prevent the unfolding humanitarian tragedy, for which the States were holding the Federal Republic, and Milosevic, directly responsible. ${ }^{122}$

The rejection of the draft resolution proposed by the Russian Federation, although significant, is not conclusive in determining the legality of the NATO intervention. We must, at this point, examine the relevant state practice on the issue.

\section{THE PRACTICE OF STATES}

In the period of the Cold War, whilst a right of intervention on humanitarian grounds found support in the writings of certain academics, ${ }^{123}$ a review of the issue by the United Kingdom Foreign Office concluded that the most favourable legal interpretation which could be advanced on behalf of relevant (humanitarian) interventions was that they could not be said to be "unambiguously illegal". ${ }^{124}$ Those interventions most commonly considered are those by India in Pakistan/Bangladesh (1971), ${ }^{125}$ Vietnam in Cambodia (1978), ${ }^{126}$ Tanzania in Uganda (1979), ${ }^{127}$ and France in Central Africa (1979). Significantly, however, there existed no clear invocation of a right of humanitarian intervention by the intervening States. ${ }^{128}$ Consequently, in the view of the United Kingdom Foreign Office, the state practice, at that time, provided "an uncertain

$121 \mathrm{~S} / 1999 / 328$

122 S/PV.3989. A similar change of emphasis is evidenced in the statements of the UN Secretary-General, who initially commented that the "[Security Council] should be involved in any decision to resort to the use of force"(SG/SM/6938), but later declared himself "deeply distressed by the tragedy taking place in Kosovo", and appeared to give some support to the NATO action by outlining certain conditions, following the acceptance of which, he would urge the leaders of the North Atlantic Alliance to suspend immediately the air bombardments upon Federal Republic of Yugoslavia" (SG/SM/6952).

123 See, for example, Lillich, "Humanitarian Intervention: A Reply to Ian Brownlie and a Plea for a Constructive Alternative", in Moore (ed.), supra n. 5, at 233; Tesón, Humanitarian Intervention: an inquiry into law and morality (1997, 2nd. ed.).

124 UK Foreign Office Policy Document No. 148 (1986) 57 BYIL 614.

125 See, generally, Franck and Rodley, supra n. 5. The General Assembly of the United Nations, in Resolution 2793, implicitly condemned the intervention calling on both sides to withdraw forces "on the territory of the other to their own side. ..": A/RES/2793(XXVI), 9 Dec., 1971.

126 The intervention was condemned by the General Assembly, Resolution 34/22, which called upon all states to "refrain from any interference in the internal affairs of [Cambodia] in order to enable its people to freely determine their own future and destiny": GA Res. 34/22 (Nov. 14, 1979).

127 See, Chatterjee, "Some Legal Problems of Support Role in International Law: Tanzania and Uganda" (1981) 30 ICLQ 755.

128 Gray, supra n. 105, at 163. In questioning before the Select Committee on Foreign Affairs, UK Government Minister, Tony Lloyd, cited the Tanzanian intervention in Uganda as a precedent for the intervention in Kosovo: HC 118i. 
basis on which to rest such a right". ${ }^{129}$ At least in the Cold War period, then, it appeared that the principle of non-intervention was held in higher regard than the need to prevent humanitarian suffering, or human rights abuses. ${ }^{130}$

In contrast, in the period since the ending of the Cold War, ${ }^{131}$ we have witnessed three instances, generally accepted as legitimate by the international community, not authorised by the Security Council, of interventions in which clear humanitarian motives were adduced by the intervening States: ${ }^{132}$ the ECOMOG intervention in Liberia (1990/1), the intervention to protect Kurdish and Shi'a populations in Iraq (1991/2), and the present NATO intervention to protect the people of Kosovo. ${ }^{133}$

129 UK Foreign Office Policy Document No. 148 (1986) 57 BYIL 614.

130 Franck, "Of Gnats and Camels: Is There a Double Standard in the United Nations" (1984) 78 AJIL 811 at 831. During the period of the Cold War, the General Assembly criticised the US intervention in Grenada (GA Res. 38/7 (Nov. 2, 1983)); the Vietnam intervention in Kampuchea/Cambodia (GA Res. 34/22 (Nov. 14, 1978)); the Soviet Union intervention in Afghanistan (GA Res. ES-6/2 (Jan. 14, 1980)); the Indian intervention in Pakistan (GA Res. 2793 (XXVI) (Dec. 7, 1971); and the Indonesian intervention in East Timor (GA Res. 3485 (XXX) (Dec. 12, 1975). The only significant intervention in the Cold-War era not to receive the disapprobation of the General Assembly was the Tanzanian intervention in Uganda.

131 We may question this difference: why accept the intervention in Liberia, a vicious, but not untypical civil war, but not intervention in Cambodia (1979), which brought an end to one of the most abhorrent regimes of the twentieth century. One clear distinction is the period in which they occurred: the intervention in Liberia was undertaken after the ending of the Cold War, and associated geo-political tensions, which followed the collapse of the Soviet Union.

Many writers have pointed to a paradigmatic shift in the norm on intervention, which has accompanied the ending of the Cold War: Kritsiotis refers to a "seachange in the attitude of states" ("Review Essay: Developing Approaches Towards Legitimising Intervention on Humanitarian Grounds" (1997) 2 Jnl Armed Conflict Law 91 at 96), whilst the US Ambassador to the United Nations, at the time of the intervention to protect the Kurds, talked of a "shift in world opinion towards a re-balancing of the claims of sovereignty and those of extreme humanitarian need" (Speech to the US Council on Foreign Relations, 8 May 1991, quoted in Freedman and Boren, "Safe-havens' for Kurds in post-war Iraq", in Rodley (ed.), supra n. 40, 43, at 82). A similar paradigm shift, in the international norm of (military) intervention, is thought to have accompanied the adoption of the Kellogg-Briand Pact of Paris 1928 (Brownlie, "Thoughts on Kind-Hearted Gunmen", in Lillich (ed.), supra n. 5, 139, at 142); the Pact was, however, a legal document, reflecting a shift in international legal relations. It is difficult to view the ending of the Cold War in the same light, and it may not be possible to identify legal developments which have effected an alteration of the paradigm of intervention.

132 One should be cautious of giving too great a significance to previous instances of state practice: see Farer, "An Inquiry into the Legitimacy of Humanitarian Intervention", in Damrosch and Scheffer (eds.), supra n. 33, 185, at 194.

133 The French intervention in Rwanda (1994) is discounted as it was seen by many to be primarily aimed at the protection of "francophonie", and France's fundamental interest against English speaking insurgents, and not humanitarian in its intentions: Bowring, “The 'Droit et Devoir D'Ingérence': A Timely New Remedy for Africa" (1995) 7 RADIC 493 at 506. 


\section{THE ECOMOG INTERVENTION IN LIBERIA (1990-1991)}

In 1990, an insurrection against the regime of President Doe of Liberia appeared on the point of success. The rebel army of Charles Taylor, the National Patriotic Front of Liberia (NPFL), and a splinter group, the INPFL, led by 'Prince' Yormie Johnson, had advanced on the capital, Monrovia, with little opposition. Whilst, in present day terms, the number of casualties was not great, the randomness of the atrocities created a terror amongst the civilian population, leading to 500,000 people, some twenty per cent of the total population, fleeing abroad, and the displacement of a further million people within the country. ${ }^{134}$ In response to the crisis, the Economic Community of West African States (ECOWAS) announced, on 6 August 1990, that, following an invitation from President Doe, ${ }^{135}$ an ECOWAS Monitoring Group (ECOMOG) would enter the country with the aim of establishing a cease-fire and restoring law and order, in order to facilitate the holding of free and fair elections. ${ }^{136}$

The Economic Community of West African States had been established in 1975 to "promote co-operation and development in all fields of economic activity" between member States: ${ }^{137}$ its concerns were primarily economic, not military. It had, though, developed a mutual assistance aspect, with elements of collective security, ${ }^{138}$ although Member States agreed to refrain from any use of force "inconsistent with the Charter of the United Nations", 139 and from intervening where a conflict remained "purely internal" to a Member state. ${ }^{140}$ In seeking to justify its intervention in Liberia, a member State of the organisation, the ECOWAS Standing Mediation Committee ${ }^{141}$ pointed to the "state of anarchy and the total breakdown of law and order in Liberia", and argued that the contending

134 Keesings Record of World Events (1990) 37644.

135 Letter addressed by President Doe to the Chairman and Members of the Ministerial Meeting of the ECOWAS Standing Mediation Committee, 14 July 1990, reprinted in Weller (ed.), Regional Peace-Keeping and International Enforcement: The Liberian Crisis (1994), p 60-61.

136 Article 2(2), ECOWAS Standing Mediation Committee, Decision A/DEC.1/8/90, on the Cease-fire and Establishment of an ECOWAS Ceasefire Monitoring Group for Liberia, 7 August 1990, reprinted in Weller (ed.), Regional Peace-Keeping, ibid., p 67.

An interim government was established, along the lines of the Liberian Constitution, but without the support of all warring factions: Interim Government of National Unity of Liberia, Final Communiqué of the National Conference, 29 August 1990, reprinted in Weller (ed.), id., p 89 - 90.

137 Treaty of the Community of West African States, 28 May 1975, Article 2, (1975) 14 ILM 1200. The original member States were Benin, Burkina Faso, Cote d'Ivoire, Gambia, Ghana, Guinea, Guinea Bissau, Liberia, Mali, Mauritania, Niger, Nigeria, Senegal, Sierra Leone, and Togo.

138 See Article 2 and 3, ECOWAS Protocol relating to Mutual Assistance on Defence, 29 May 1981, reprinted in Weller (ed.), Regional Peace-Keeping, supra $\mathrm{n} .135, \mathrm{p} 19$.

139 Article 1, ECOWAS Protocol on Non-Aggression, 22 April 1978, reprinted in Weller (ed.), ibid, p 18.

140 Article 18 of the ECOWAS Protocol relating to Mutual Assistance on Defence, supra n. 138.

141 Established by Decision A/DEC. 9/5/90, 30 May 1990 by ECOWAS Heads of State and Government, reprinted in Weller (ed.), Regional Peace-Keeping, supra $\mathrm{n} .135, \mathrm{p} 38$. 
factions were "holding the entire population as hostage, depriving them of food, health facilities and the other bases necessities of life". ${ }^{142}$ This, the Committee argued, justified the intervention by ECOMOG forces.

The legal basis for the intervention is not clear; although the absence of any express Security Council resolution authorising the ECOMOG action prevents us, on a rigorous interpretation, from justifying it under the provisions on collective security under the Charter of the United Nations. Whilst the Security Council did not authorise the intervention, it did, though, indicate its support for it ${ }^{143}$ notably in the adoption of Resolution 788 , which imposed an arms embargo on all forces in Liberia - with the exception of the ECOWAS peacekeeping troops. ${ }^{144}$ The absence of condemnation by the Council, and indeed its apparent tacit support, is not, however, conclusive in establishing the legality of the intervention; nor is the invitation by President Doe for ECOMOG forces to enter the country. The lack of control of any significant territory by the Government, ${ }^{145}$ taken with the absence of any foreign assistance to the rebel forces, and the rejection of the ECOMOG intervention by the main rebel faction, ${ }^{146}$ must lead us to question the right of the Doe regime to invite into the country external military forces. Moreover, in previous interventions, notably in the Congo ${ }^{147}$ and Grenada, ${ }^{148}$ the existence of an invitation by the Government to outside forces did not prove conclusive in determining the legality of the actions of the intervening States. ${ }^{149}$

142 Para. 7, ECOWAS Standing Mediation Committee, Final Communiqué of the First Session, 7 August 1990, reprinted in Weller (ed.), ibid., p 72 - 3.

143 See, Note(s) by the President of the United Nations Security Council, 2974th Meeting, 22 January 1991, S/22133, 3071st Meeting, 7 May 1992, S/23886.

144 SC Res. 788 (1992).

145 The position is unclear, with the rebel forces claiming to "dissolve" the Doe Government at one point (Report: Doe Government 'Dissolved', BBC Monitoring Report, 27 July 1990, reprinted in Weller (ed.), Regional PeaceKeeping, supra n. 135, p 62); yet, the same rebel forces later refused to accept a cease-fire unless Doe "resigned" (Report: NPFL Tells ECOWAS No Ceasefire Till Doe Goes, BBC Monitoring Report, 9 August 1990, reprinted in Weller (ed.), id., p 62).

146 Report: Taylor Opposes Foreign Intervention, BBC Monitoring Report, 5 August 1990, reprinted in Weller (ed.), Regional Peace-Keeping, ibid., p 63.

There has been a shift, in international practice, away from recognising governments, to dealing with those who have 'effective control' of the territory. Consequently, in considering the legality of a relevant intervention, we would be concerned with the consent, or absence thereof, of the governing authorities, not the government. We may note, for example, the need for the adoption of Security Council Resolution 940 (SC Res. 940 (1994)) to authorise military force to remove the junta which has seized power in Haiti; presumably, the authorisation of the legitimate President, Aristide, was insufficient to legitimise military intervention.

147 See, Franck and Rodley, supra n. 5, at 287.

148 The US intervention in Grenada was condemned by the General Assembly: GA Res. 38/7 (1983); cf. Moore, "Grenada and the International Double Standard" (1984) 78 AJIL 145 at 156.

149 See, Kirgis, "NATO Consultations as a Component of National Decisionmaking" (1979) 73 AJIL 372 at 398; cf. Bowett, "The Interrelation of Theories of Intervention and Self-Defence", in Moore (ed.), supra n. 5, 38 at 42 . 
The legality of the ECOMOG intervention in Liberia is, then, difficult to determine in the absence of a wider consideration of the relationship between the prohibition on aggressive intervention and the need to prevent humanitarian suffering.

\section{THE ALLIED INTERVENTION IN IRAQ (1991/2)}

In the aftermath of the defeat of Iraq by the allied coalition in 1991,150 uprisings took place, against the regime of Saddam Hussein, in northern and southern Iraq, by Kurdish forces and Shi'a rebels respectively. Although initially enjoying some success, they were brutally suppressed by superior Iraqi government forces. In the north this resulted in over one million refugees fleeing towards neighbouring States, who refused them entry. ${ }^{151}$ Responding to an impending "human tragedy of appalling dimensions", ${ }^{52}$ created by the refugee crisis, ${ }^{153}$ the United States, United Kingdom and France used military force to protect the Iraqi civilian population. ${ }^{154}$

Initially, the allied forces simply provided humanitarian assistance to the refugees, ${ }^{155}$ subsequently, however, relief camps were established to encourage the, mainly, Kurdish refugees to return home, ${ }^{156}$ and, finally, a "safe-haven"157 and no-fly zone, north of the $36^{\text {th }}$ parallel, 158 were established to protect the returning refugees from Iraqi forces. One year later, following reports of "systematic murder ... genocide [and] . . . bombing by Saddam from the air", 159 a similar no-fly zone was introduced, below the $33^{\text {rd }}$ parallel, to protect Shi'a and Marsh Arab populations in the south of the country. Iraq was warned that infringements of the safehaven, or the no-fly zones, would not be tolerated, and military force would be used to protect the integrity of both. ${ }^{160}$

150 The conflict concluded with the adoption, by the Security Council, of a ceasefire resolution (SC Res. 687 (1991)), which took effect on 11 April 1991.

151 See the comments of Turkey and Iran's representatives to the Security Council in the debate, on 5 April 1991, leading up to the adoption of Resolution 688: L. S.PV2982.

152 "Statement by the UK Prime Minister: A Safe Haven for the Kurds", reprinted in Weller (ed), Iraq and Kuwait: The Hostilities and Their Aftermath (1993), p 714.

153 See, Malanczuk, "The Kurdish Crisis and Allied Intervention in the Aftermath of the Second Gulf War" (1991) 14 EJIL 114 at 118.

154 See, generally, Adelman, "Humanitarian Intervention: The Case of the Kurds" (1992) 1 International Journal of Refugee Law 4 at 19-23.

155 See "Statement by the UK Prime Minister", supra n. 152; also the Letter(s) from the Permanent Representative of Iraq to the United Nations which condemned the action as an infringement of Iraqi sovereignty: S/22459, 8 April 1991, reprinted, Weller (ed.), Iraq and Kuwait, supra n. 152, p 716.

156 See, on this point, US President's News Conference, 16 April 1991, Volume 27, No. 16, Weekly Compilation of Presidential Documents, reprinted in Weller (ed.), ibid., p 717.

157 The idea of 'safe-havens' was initiated by British Prime Minister Major at a meeting of EC Heads of Government in Luxembourg, 8-9 April 1991: "Statement by the UK Prime Minister", supra n. 152.

158 See, Malanczuk, supra n. 153, at 120.

159 Transcript of interview given by UK Prime Minister, John Major, 18 August 1992: reprinted in Weller (ed.), Iraq and Kuwait, supra n. 152, at 723.

160 Statement issued by members of the Coalition at New York, 26 August 1992, reprinted in Weller (ed.), ibid., at 725. At the time of writing, US and UK 


\section{Northern Ireland Legal Quarterly [Vol. 50, No. 4]}

The legal basis for the intervention by allied forces has never been clearly articulated; indeed it has been suggested that "the underlying assumption of the USA, the UK and France seems to have been that this was a special situation of victorious powers acting against a defeated state and so no rigorous legal justification was needed". 161 Much was made, at the time, of the adoption by the Security Council of Resolution 688, 162 which "condemned the repression of the Iraqi civilian population. . . . the consequences of which threaten[ed] international peace and security". ${ }^{16}$ The Resolution, adopted under Chapter VII of the Charter, clearly indicated the concern of the Council as to the position of the civilian population in Iraq; ${ }^{164}$ it did not, however, authorise the use of force, ${ }^{165} \mathrm{a}$ fact recognised by the United Kingdom Foreign Office, ${ }^{166}$ which, in contrast, has attempted to justify the intervention by reference to the customary international law principle of humanitarian intervention, which legitimates the use of military force "in cases of extreme humanitarian need". 167

\section{THE CRITERIA FOR INTERVENTION ON HUMANITARIAN GROUNDS}

We have three clear instances of States intervening to prevent humanitarian suffering, and being prepared to ground their right to intervene in the need to prevent such suffering. Whilst we might be sympathetic to the claims of legitimacy for the interventions considered here, we should be wary of accepting any exception to the general prohibition on the use of armed force - and in particular any exception grounded in criteria as vaguely defined as the need to prevent a

aircraft, patrolling the no-fly zones, continue to employ military force, in Iraqi airspace, when challenged by Iraqi forces: see, for example, The Times, 23 August 1999.

161 Gray, supra n 105, at 163.

162 UK Foreign Secretary Hurd talked of "proposals . . . to help provide emergency aid, as authorised by Security Council resolution 688": HC Debs. 17 April 1991, reprinted in Weller (ed.), Iraq and Kuwait, supra n. 152, at 720 (In December 1998, the British Defence Secretary relied upon Security Council Resolution 688 to justify the southern no-fly zones: The Guardian, 31 December 1998.) $C f$. Gray: "Resolution 688, although referred to at the time by the States involved, does not authorize forcible humanitarian intervention", supra $\mathrm{n} 105$ at 162.

163 SC Res. 688 (1991), adopted by ten votes to three (Cuba, Yemen, and Zimbabwe voting against; China and India abstaining).

164 Delbrück, supra n. 41, at 894-5, footnotes omitted.

165 Warbrick, "The Invasion of Iraq - Part II" (1991) 40 ICLQ 965 at 972; cf. Greenwood, "New World Order or Old? The Invasion of Kuwait and the Rule of Law", 55 MLR (1992) 153 at 177.

166 Aust, Legal Counsellor, FCO, evidence to House of Commons Select Committee, reprinted "UK Materials in International Law" (1992) 63 BYIL 828

167 Ibid. at $826-7$. 
humanitarian catastrophe; ${ }^{168}$ the intervening States are, after all, likely to be "the sole judge[s] of the necessity of the intervention" in question. ${ }^{169}$

There are a limited number of states with the military capacity to undertake such interventions, even at the regional level; on the global level the number is reduced to one: the United States. ${ }^{170} \mathrm{~A}$ right of intervention without clear criteria for its application presents the real danger of legitimising aggressive intervention under the guise of humanitarian objectives. ${ }^{171}$ In the present instance, NATO States did not seek to argue that they were the sole arbiters of the necessity of intervention:

"a limited use of force [is only] justifiable in support of purposes laid down by the Security Council but without the Council's express authorisation, when that was the only means to avert a humanitarian catastrophe. Such cases would in the nature of things be exceptional and would depend on an objective assessment of the factual circumstances at the time and on the terms of the relevant decisions of the Security Council bearing on the situation in question". ${ }^{172}$

Thus, before an intervention could be undertaken, there would have to be a determination by the Security Council that the sufferings endured by human persons, in a given population, had reached such a magnitude as to constitute a threat to peace and security. ${ }^{173}$ Only where the Security Council proved unwilling, or unable, to act, and following the exhaustion of all diplomatic efforts, could a determination be made to use military force. ${ }^{174}$

168 Brownlie has described the (previous) definitions of humanitarian intervention as "woefully slack", leaving, in its application, the right wide open to abuse: Brownlie, "Thoughts on Kind-Hearted Gunmen", in Lillich (ed.) Humanitarian Intervention and the United Nations (1973) 139, at 146.

169 Fairley, supra n. 5, at 61.

170 See, as an example of military intervention by the United States in pursuit of its (self-interested) foreign policy, the cruise missile attacks, on 20 August 1998, against a plant suspected of making nerve gas in Sudan and a suspected terrorist base in Afghanistan. The justification given was the "imminent threat to US national security ... . [posed by] the bin Laden terrorist network": Keesings Record of World Events (1998) 42435. The attacks received only limited support from the international community, ibid., 42436.

171 Most notoriously, Hitler referred to humanitarian motives to justify German interventions in Czechoslovakia and Poland: Franck and Rodley, supra n. 5, at 284.

172 Minister of State, Tony Lloyd, Minutes of Evidence to the Foreign Affairs Select Committee, 26 January 1999: HC 118-i. Security Council concerns are evidenced in the "Statement(s) by the President of the Security Council", on 19 January 1999, following the massacre at Racak (S/PRST/1999/2), and 29 January 1999 (S/PRST/1999/5).

173 Supra n. 42.

$174 C f:$ : "We do not have a formal set of criteria to apply in assessing whether or not the level of suffering in a particular emergency justifies intervention for humanitarian purposes": FCO Memorandum to HC Foreign Affairs Select Committee, reprinted "UK Materials in International Law" (1992) 63 BYIL at 826. 
The creation of a right of intervention would not, however, create an obligation to intervene. ${ }^{175}$ British Prime Minister Blair has outlined the criteria to be borne in mind in determining when and whether the United Kingdom should intervene to prevent humanitarian suffering:

"First, are we sure of our case? . . . Second, have we exhausted all diplomatic options? ... Third, on the basis of a practical assessment of the situation, are there military operations we can sensibly and prudently undertake? Fourth, are we prepared for the long term? . . . And, finally, do we have national interests involved? The mass expulsion of ethnic Albanians from Kosovo demanded the notice of the rest of the world. But it does make a difference that this is taking place in such a combustible part of Europe". 176

Should, though, national interests be relevant in deciding when, and whether, to intervene on humanitarian grounds. Concern has arisen in the past from the selective application of the humanitarian interventions undertaken, ${ }^{177}$ and the perceived 'real' motives of the intervening states; why intervention in the Federal Republic of Yugoslavia, but not, until recently, in support of the people of East Timor, ${ }^{178}$ and not in the case of the suffering of the people of Ethiopia: ${ }^{179}$ indeed, as Franck and Rodley note, "history is all too replete with instances in which one would have expected states claiming the existence of a right of humanitarian intervention to have sent their armies to the rescue", and where they did not do so. ${ }^{180}$

Selectivity of application is a feature of all legal systems, although it does create particular problems in a legal system which decentralises enforcement - as international law does. It is a matter of international realpolitik that a state will only elect to exercise a right of intervention where it views some benefit for itself in that intervention. This is not to suggest that selfish interests will inevitably outweigh humanitarian ones simply that most cases of humanitarian intervention will be "mixed motive cases", 181 and certain motives may be less than altruistic. This is certainly the case in the present instance, with the US State Department being explicit in its acceptance that the intervention in the Federal Republic of Yugoslavia was a mixed motive case. ${ }^{182}$ Might we not, though, given such

175 Cf. Koroma, "Humanitarian Intervention and Contemporary International Law" (1995) 4 SZIER 409 at 413 - 4.

176 "Doctrine of the International Community", speech given in Chicago, USA, 22 April 1999: <www.number-10.gov.uk/public/news/index.html> (emphasis added).

177 Minear asks: "is not all human life deserving of protection?": "A Strengthened Humanitarian System for the Post-Cold War Era", in Minear, Weiss and Campbell (eds.), Humanitarianism and War: Learning the Lessons from Recent Armed Conflicts (Occasional Paper No. 8, Thomas J. Watson Jr. Institute for International Studies, Brown University) (1991) 29, at 38.

178 SC Res. 1264 (1999). See, generally, on the issues raised, Clark, "The 'Decolonization' of East Timor and the United Nations Norms on SelfDetermination and Aggression" (1980) 7 Yale Jnl of World Public Order 2.

179 Bazyler, supra n. 86, at 618 - 9.

180 Franck and Rodley, supra n. 5, at 290.

181 Wright, "A Contemporary Theory of Humanitarian Intervention”, 4 Florida International Law Journal (1989) 435 at 460.

182 "We have three strong interests at stake in the Kosovo conflict: averting a humanitarian catastrophe; preserving stability in a key part of Europe; and 
an acceptance, question the humanitarian justification advanced; should not humanitarian interventions be undertaken "without self-interest or expectation of national, political, economic or military gain". ${ }^{183}$

The relative purity of the humanitarian motive adduced by the intervening state is, though, difficult, if not impossible, to determine. Consequently, whilst the intervening state would be required to advance humanitarian concerns in justifying its actions, ${ }^{184}$ the veracity of that claim may only be judged by reference to factors surrounding the intervention: inter alia, was it undertaken unilaterally, or with the support of other states; ${ }^{185}$ was it proportionate to the stated aims, and limited in time and scope to the achievement of those aims; and importantly, did it fall within the limits established by relevant Security Council resolutions. Moreover, whilst any act of humanitarian intervention will, prima facie, violate the sovereign rights of the target state, we should consider the extent to which the intervention sought to uphold the right of the people on whose behalf the intervention was nominally undertaken to self-determination:

"[T]he rights enshrined by the UN should be enjoyed by peoples, and should not be confined to Governments. No Governments have the right to defend, on grounds of sovereignty, oppression of their people and ethnic cleansing such as occurred in Kosovo". ${ }^{186}$

Consequently, a lawful and legitimate act of humanitarian intervention would respect the right to self-determination of the people whose

maintaining the credibility of NATO": "US and NATO objectives and Interests in Kosovo", Fact Sheet released by the U.S. Department of State, Washington, DC, March 26 1999:

<www.state.gov/www/regions/eur/fs_990326_ksvobjectives.html>.

183 Wright, supra n. 181, at 459 (footnotes omitted).

184 If this requirement did not exist, we might find ourselves legitimising 'accidental humanitarian interventions'. For example, where an intervention was undertaken for the purpose of acquiring the territory of another state (clearly unlawful and 'aggressive'), and the invading forces engaged the target state's armed forces whilst the latter were en route to massacre one of the target state's minority communities, the intervention would clearly have humanitarian outcomes; it could not, however, be considered a 'humanitarian intervention'. See, for example, the Vietnamese intervention in Cambodia, which had self-evident humanitarian outcomes, but was undertaken with a view to furthering Vietnamese regional hegemony.

185 On the position in the pre-Charter era, see Liszt, International Law in a Systematic Exposition (1917), p 87, referred to in Kartashkin, "Human Rights and Humanitarian Intervention", in Damrosch and Scheffer (eds.), supra n. 33, 202, at 204. An exception existed only where the intervening state was authorised to do so by the international community; see, for example, the case of the French intervention in Syria (1860-1861): Fonteyne, supra n. 5, at 208 209.

Considering the United Nations era, we might note, as an example of the reluctance of the international community to endorse unilateral intervention, the negative reaction to the United States' cruise missile attacks on Iraq, which followed Iraqi military actions in the Kurdish safe area; this despite the humanitarian concerns adduced by the US: Symes, "Force Without Law: Seeking a Legal Justification for the September 1996 U.S. Military Intervention in Iraq" (1998) 19 Michigan Jnl International Law 581 at 598.

186 Robin Cook, HC Debs. 20 April 1999, col. 680. 
liberation from humanitarian suffering is the very raison d'être of the intervention. ${ }^{187}$

\section{HUMANITARIAN INTERVENTION AND SELF-DETERMINATION}

Should a right of intervention on humanitarian grounds not, then, be grounded in the right to self-determination itself; ${ }^{188}$ indeed, certain writers have argued that self-determination provides the basis of a right of "unilateral intervention... outside the collective framework of the Security Council" in circumstances where the rights of the human person are being violated. ${ }^{189}$

Such an approach should not be taken as suggesting that every instance of a violation of the right to self-determination would give rise to a right of intervention; ${ }^{190}$ the failure, for example, of a government to introduce or restore democratic government would not justify military action against

187 The imposition of a government on that people would remove any claim for purity of motive, and semblance of legality. We may, then, discount the humanitarian claims of Indonesia's intervention in East Timor (1975) and South Africa's intervention in Namibia (1975). Such interventions were clearly aimed at violating the rights of the respective peoples to self-determination, irrespective of the human rights situation before and after the interventions.

188 The legal right to self-determination is confirmed in the Charter of the United Nations (Articles 1 and 73). Its application to the independence of colonial peoples from the metropolitan state was affirmed by the United Nations General Assembly (GA Res. 1514 (XV), 14 December 1960, 'Declaration on the Granting of Independence to Colonial Territories and Peoples'), and by the International Court of Justice (Western Sahara Case ICJ Rep. 1975 12). However, the right is not restricted to colonial situations: Common Article 1, International Covenant on Civil and Political Rights, and International Covenant on Economic Social and Cultural Rights (1966)): "All peoples have the right to self-determination". This acceptance, of a right of 'all' peoples to self-determination, led to the recognition of an 'internal' aspect of the right: Cassese, Self-Determination of Peoples (1995) 101 - 40, passim.

Both the issue as to which groups constitute a 'people' (see, for example, Final Report and Recommendations of an International Meeting of Experts on the Further Study of the Concept of the Right of People for UNESCO (1990), SNS-89/CONF.602/7), and the content of the right remain highly contentious: see, Declaration on Principles of International Law Concerning Friendly Relations and Co-Operation Among States, supra n. 27; the Human Rights Committee's General Comment 12, Article 1 (Twenty-first session, 1984), U.N. Doc. HRIIGEN\1\Rev.1 at 12 (1994); Pellet, "The Opinions of the Badinter Arbitration Committee - A Second Breadth for the SelfDetermination of Peoples" (1992) 3 EJIL 178; McCorquodale, "SelfDetermination: A Human Rights Approach" (1994) 43 ICLQ 857; and Quane, "The United Nations and the Evolving Right to Self-Determination" (1998) 47 ICLQ 537.

189 Akhavan, "Lessons from Iraqi Kurdistan: Self-Determination and Humanitarian Intervention Against Genocide" (1993) 1 Neths. Quarterly Human Rights 41 at $61-2$. On intervention in support of the right to selfdetermination, generally, see Walzer, Just and Unjust Wars (1978), p 87-91; Navari, "Intervention, Non-Intervention and the Construction of the State", in Forbes and Hoffman, Political Theory, Intervention Relations and the Ethics of Intervention (1993) 43.

190 See, on this point, Bowett, "The Interrelation of Theories of Intervention And Self-Defence", in Moore (ed.), supra n. 5, 38, at 43-4. 
that state. ${ }^{191}$ Only in circumstances where a government turned savagely on its own people, and in which we might "doubt the very existence of a political community to which the idea of self-determination might apply", 192 would intervention be permitted. ${ }^{193}$ This approach would provide a clear normative basis for humanitarian intervention, and clear limits on its application: intervention in support of an oppressed people, or minority people within a state, would be lawful; intervention in support of a minority group would not. ${ }^{194}$ Nor would an intervention undertaken to protect a group of individuals from unjust execution be lawful, even if one of the individuals were Mahatma Ghandi; ${ }^{195}$ nor a military operation to assassinate a political leader, including Milosevic, to prevent humanitarian suffering. ${ }^{196}$

Moreover, as a rule of jus cogens character, ${ }^{197}$ the right to selfdetermination is in principle capable of modifying the prohibition on the use of force, ${ }^{198}$ and instances of intervention in support of the right have enjoyed a certain degree of acceptability within the international community, ${ }^{199}$ despite a less than upstanding record. ${ }^{200}$ Consequently, we

$191 C f$. "Self-determination postulates the right of a people. . . to determine its collective political destiny in a democratic fashion ... ": Franck, "The Emerging Right to Democratic Government" (1992) 86 AJIL 86 at 52; see, also, the views of the UN Secretary-General, Kofi Anan, responding the removal of the democratic government in Sierra Leone: "Where democracy has been usurped let us do all in our power to restore it to the people", The Guardian, 3 June 1997.

192 Walzer, supra n. 189, p 101

193 See, on this point, Arend and Beck, International Law and the Use of Force (1993), p 113. This view is contested by Donnelly, who contends that such an argument "confuses the injustice of the regime with the right of others to remedy the injustice": Donnelly, supra n. 77, at 319.

194 A distinction is drawn, in international law, between the rights of 'peoples' and minority groups: see, respectively, Articles 1 and 27 of the International Covenant on Civil and Political Rights (1996). See, on this point, Mullerson, "Minorities in Eastern Europe and the Former USSR: Problems, Tendencies and Protection" (1993) 56 MLR 808, and Bothe, "The legitimacy of the Use of Force to Protect Peoples and Minorities", in C. Brölmann et al. (eds.), Peoples and Minorities in International Law (1993) 289, at 299.

195 Wright, supra n. 181, at 462.

196 See Brandenburg, "The Legality of Assassination as an Aspect of Foreign Policy" (1987) $27 \mathrm{Va}$. J. Int'l Law 655 at 671 - 680; although he notes: "It would be difficult to argue that the removal of Hitler before World War II would not have been justified to halt the Holocaust", ibid, at 695 (it would not, of course, on his analysis have been lawful).

197 East Timor Case (Portugal v Australia) ICJ Rep. 199590 at para. 29.

198 See, on this point, General Assembly Declaration on Principles of International Law Concerning Friendly Relations, supra n. 27: “. . . in pursuit of their exercise of self-determination, such peoples are entitled to seek and receive support in accordance with the purposes and principles of the Charter" (emphasis added).

199 See, Adelman, supra n. 154, at 30. We might note the acceptance by the international community of India's intervention in Portuguese Goa in December 1961 (Pomerance, supra n. 35, p 49 - 50); and the United States' support of the Mujahadin rebels in Afghanistan following the Soviet intervention (Arend and Beck, supra n. 193, p 80-92). 
might have expected NATO States to rely on the right to selfdetermination in justifying their intervention in the Federal Republic of Yugoslavia - particularly given that it is generally accepted that the failure of the Federal Republic to agree appropriate autonomy for Kosovo, ${ }^{201}$ along the lines demanded by the Security Council, ${ }^{202}$ amounted to a clear violation of the Kosovar people's right to self-determination. ${ }^{203}$ As already noted, NATO States did not, however, seek to ground their right of intervention in the violation of this right; ${ }^{204}$ they did, though, see its effective implementation as central to any effective settlement of the crisis.

The coupling of a right of intervention on humanitarian grounds with the right to self-determination has significant consequences for the scope of any proposed intervention. A right of humanitarian intervention simpliciter would only grant NATO States the right to intervene "insofar as it is necessary and proportionate for the purpose of humanitarian protection" ${ }^{205}$ that is, the protection of the Kosovar Albanians from the unfolding humanitarian tragedy. A right of intervention on humanitarian grounds simpliciter could not justify two of the central objectives of the NATO intervention: the return the refugees to their homes, when those refugees were already safe in camps in Macedonia and Albania; and the establishment of self-government and autonomy for the Kosovo region. ${ }^{206}$ In contrast, the coupling of humanitarian intervention with the right to self-determination would allow permit an intervention aimed at facilitating a right to return home, and the alteration of the structures of government or state, beyond that required for motives which were strictly

200 Self-determination is referred to, inter alia, by the United States and Soviet Union in justifying their interventions in Vietnam and Hungary respectively; in the case of Grenada, the Americans intervened (in part) to restore democratic government; and India referred to Pakistan's rule in East Pakistan (Bangladesh) as "colonial": Franck and Rodley, supra n. 5, at 276.

201 See, generally, Hannum, Autonomy, Sovereignty, and Self-Determination: The Accommodation of Conflicting Rights (1990).

202 "[The Security Council agrees] without prejudging the outcome of that dialogue, with the proposal in the Contact Group statements of 9 and 25 March 1998 that the principles for a solution of the Kosovo problem should be based on the territorial integrity of the Federal Republic of Yugoslavia and should be in accordance with OSCE standards, including those set out in the Helsinki Final Act of the Conference on Security and Co-Operation in Europe of 1975, and the Charter of the United Nations, and that such a solution must also take into account the rights of the Kosovar Albanians and all who live in Kosovo, and expresses its support for an enhanced status for Kosovo which would include a substantially greater degree of autonomy and meaningful selfadministration": S/RES/1160 (1998), para. 5.

203 For consideration of whether the Kosovar Albanians constitute a people, see Caplan, supra n. 7, at 747 - 750.

204 The application of self-determination requires a territory within which the defined people may exercise their right to self-determination. For our purposes, the defined territory would be the region of Kosovo and the relevant people the 'Kosovar people', not the 'Kosovar Albanians'. It is clearly vital, therefore, that the NATO intervention has the effect of guaranteeing human rights to all Kosovar peoples, including the minority Serb population.

205 Kritsiotis, "Reappraising Policy Objections to Humanitarian Intervention" (1998) 19 Michigan Journal of International Law 1005 at 1038.

206 Prime Minister Blair, "Doctrine of the International Community", supra n. 176. 
humanitarian:207 the establishment of an autonomous region under international supervision, beyond the control of the target state. ${ }^{208}$

\section{THE NATO INTERVENTION IN THE FEDERAL REPUBLIC OF YUGOSLAVIA: A JUST WAR?}

If, as has been suggested, the purpose of international law "is to assist in the achievement of an international stability that is consistent with justice and in the realisation of shared values", ${ }^{209}$ the intervention by NATO States must give cause for concern, given the evident absence of shared values in the Security Council. Indeed the action may be open to the accusation of benign imperialism, and a return to the "civilized versus non-civilized nations" 210 divide implicit in pre-Charter instances of humanitarian intervention, as western values are imposed on other states by military force. This judgement is, however, on examination, difficult to sustain. Whilst the intervention was characterised by the British Prime Minister as a "...just war, based not on any territorial ambitions but on values", ${ }^{11}$ those values were not archetypal western (liberal) ones such as those espoused by, for example, John Rawls ${ }^{212}$ or Michael Walzer: ${ }^{213}$ human rights and self-determination respectively.

NATO intervened in response to the inevitable humanitarian suffering in Kosovo which followed the adoption, by the Serb authorities, of policies of virulent ethno-nationalism, ${ }^{214}$ and the repudiation by the Milosevic regime of universal standards established by the international community for respect for the human person. ${ }^{215}$ In determining the legitimacy of the intervention by NATO States from an ethical viewpoint, this would not seem to be a "difficult case":216 any genuine concept of transnational

207 Pease and Forsythe, supra n. 81, p 300; see, also, Gillespie, "Unwanted Responsibility: Humanitarian Military Intervention to Advance Human Rights" (1993) 18 Peace and Change 219 at 235-6.

208 See, on this point the Declaration on Principles of International Law Concerning Friendly Relations, supra n. 27: "Nothing in the foregoing paragraphs shall be construed as authorising or encouraging any action which would dismember or impair. . . the territorial integrity or political unity of sovereign and independent States conducting themselves in compliance with the principle of ... self-determination of peoples. . .". In cases of 'federal' type states, the creation of a new state within the previous federal borders may be acceptable. See, generally, the opinions of the Badinter Committee on Yugoslavia, in Pellet, supra. n. 188. Such an argument would, for example, justify the actions of India in creating the new State of Bangladesh following its intervention in Pakistan (1971). In the present case, the international community is, for a number of reasons, opposed to independence for the Kosovo: Caplan, supra n. 7, at 755.

209 Higgins, supra n. 42 at 95

210 Fonteyne, supra n. 5, at 227.

211 Prime Minister Blair, "Doctrine of the International Community", supra n 176.

212 Rawls, A Theory of Justice (1972).

213 Walzer, Just and Unjust Wars (1978).

214 See, generally, Brown, "Are there good and bad nationalisms?" (1999) Nations and Nationalisms 281.

215 See, Foreign Secretary Cook, "It is fascism that we are fighting", The Guardian, 5 May 1999.

216 Cf. Frost, Ethics in International Relations: A Constitutive Theory (1996), p 2 3 . 


\section{Northern Ireland Legal Quarterly [Vol. 50, No. 4]}

justice would demand intervention. ${ }^{217}$ Those commentators who have criticised the intervention must consider the extent of the humanitarian tragedy which would inevitably have followed the actions of the Serb authorities had NATO not acted, and the consequential animadversion directed at the organisation had the most powerful military alliance in the world stood idly by whilst the Milosevic regime ethnically cleansed the Kosovar Albanian population.

An acceptance of the legitimacy of the NATO action should not, though, blind us as to certain concerns as to the manner of its undertaking. As part of its submissions during the oral pleadings in Case Concerning Use of Force, the Federal Republic argued that, whatever the merits of the claimed right of intervention on humanitarian grounds, the modalities for the intervention selected by NATO disqualified this intervention as a humanitarian one. In support of this argument, the method of high level bombing, which created minimum risk for the aircrew, but maximum risk to the civilian population, and the bombing of populated areas with consequential civilian casualties, were highlighted. ${ }^{218}$ There are, selfevidently, clear ethical and practical imperatives for conducting a humanitarian war by the least inhumane methods; it is, though, difficult to discern what legal requirements could be incumbent upon the intervening state, or states, beyond those found in the relevant Geneva Conventions, and in the laws and customs of war, for the conduct of an intervention which was specifically humanitarian. ${ }^{219}$

Whatever the ethical arguments which may be adduced in support of the NATO intervention, there are particular demands that military interventions, undertaken for whatever purpose, are subject to the rule of law. ${ }^{220}$ Moreover, conclusions as to the legality of the NATO intervention cannot be derived from the "rhetorical persuasiveness" 221 of arguments which would seek to affirm a right of humanitarian intervention, inter alia, in utilitarian theories, ${ }^{222}$ principles of natural law, ${ }^{223}$ concepts of justice ${ }^{224}$ or the "people's sovereignty":225 "the legal debate on humanitarian intervention cannot be won on some moral high ground or on the sole basis of some fundamental humanitarian principle or ideal". ${ }^{226} \mathrm{We}$

217 On the ethical arguments for accepting 'humanitarian intervention', see, Donnelly, supra n. 77, at 312 .

218 Oral Pleadings, Case Concerning Legality Use of Force, 10 May 1999: <www.icj-cij.org>.

219 Uniquely, in the present case, an international tribunal, the International Criminal Tribunal for the former Yugoslavia, enjoys compulsory jurisdiction, under Article 1 of its Statute, to prosecute individuals for all breaches committed in "the territory of the former Yugoslavia" of the Geneva Conventions (Article 2), violations of the laws or customs of war (Article 3), genocide (Article 4), and crimes against humanity (Article 5): Statute of the International Criminal Tribunal for the Former Yugoslavia, Annex to SC Res. 827 (1993), (1993) 32 ILM 1203.

220 Fairley, supra n. 5, at 62.

221 Franck, "Conference Proceedings", in Lillich (ed.), supra n. 5, p 13.

222 See, for example, the discussion in Wright, supra n. 181, at 445 - 6.

223 See Meron, "Common Rights of Mankind in Gentili, Grotius and Suárez" (1991) 85 AJIL 110.

224 Tesón, "The Kantian Theory of International Law" (1992) 92 Colombia Law Review 84; see also Laberge, supra n. 82.

225 Reisman, "Sovereignty and Human Rights in Contemporary International Law" (1990) 84 AJIL 866 at 869.

226 Kritsiotis, supra n. 205, at 1049 (emphasis added). 
must concern ourselves with the relevant international law on the issue, and examine the intervention in the light of the law as we find it, not how we might wish it to be. ${ }^{227}$

\section{CONCLUSION: THE LEGALITY OF THE NATO INTERVENTION}

The range of human rights treaties adopted during the period of the United Nations and provisions on the treatment of civilian populations during periods of armed conflict evidence minimum standards for the treatment of, and respect for, the human person. No state may exclude the legitimate interests of the international community when it treats its population in the manner in which the Federal Republic of Yugoslavia treated the Kosovar Albanian population, or indeed the way in which the various Liberian factions treated the people of that State, or the Iraqi government the Kurdish, and other minority populations of Iraq: that much is clear in the international legal order. The key question, for this article, is whether those states who have intervened by military force, without Security Council authorisation, to end or prevent a humanitarian catastrophe, have acted in contravention of the Charter of the United Nations, given the provisions of Article 2(4).

In contrast to the preceding era, the post-Cold war period has evidenced acceptance by the international community of the legitimacy of instances of intervention by military force to prevent humanitarian suffering, where a humanitarian crisis reaches a point of such seriousness and magnitude to be recognised by the Security Council of the United Nations as constituting a threat to peace and security. A significant feature of these post-Cold War interventions has been the willingness of the intervening States to assert a right of intervention on humanitarian grounds; this may be contrasted with the Cold War period when a less contentious basis for the resort to armed force, such as self-defence, was invariably argued. This factor, taken with the acceptance of these interventions by the majority of States, requires us to recognise a paradigmatic shift in the international norm on the use of armed force under the Charter of the United Nations. It is now clear that a significant, but limited, exception to the prohibition contained in Article 2(4) exists: in circumstances where the Security Council has recognised that an existing, or impending, humanitarian catastrophe constitutes a threat to peace and security, a limited use of force is justifiable in support of purposes laid down in relevant Security Council resolutions, without the Council's express authorisation, where that is the only means by which the humanitarian catastrophe may be avoided.

In the present case, it is clear that the international community, and the Security Council, had recognised that a humanitarian catastrophe was imminent in Kosovo, as a direct consequence of the actions of the Serb authorities. NATO States, with long experience of dealing with President Milosevic, determined that military force was the only method by which the civilian population in Kosovo could be protected. This determination, and the military intervention itself, was, in general, supported by member States of the United Nations (with the clearest evidence of this being seen in the rejection of the Russian proposed resolution condemning the intervention). Moreover, the NATO intervention was undertaken with the aim of achieving the objectives laid out in the resolutions adopted by the Security Council on the issue. Consequently, the NATO action, undertaken to protect the Kosovar Albanian population from the

227 However, if a given act of humanitarian intervention were judged illegal, "[a] further question would be [in Kantian language] 'is the law just?'": Laberge, supra $\mathrm{n}$. 82, at 15 - 16 (footnotes omitted). 
512 Northern Ireland Legal Quarterly [Vol. 50, No. 4]

humanitarian catastrophe unfolding around them, may be considered a clear instance of lawful humanitarian intervention in the post-Cold War era. 